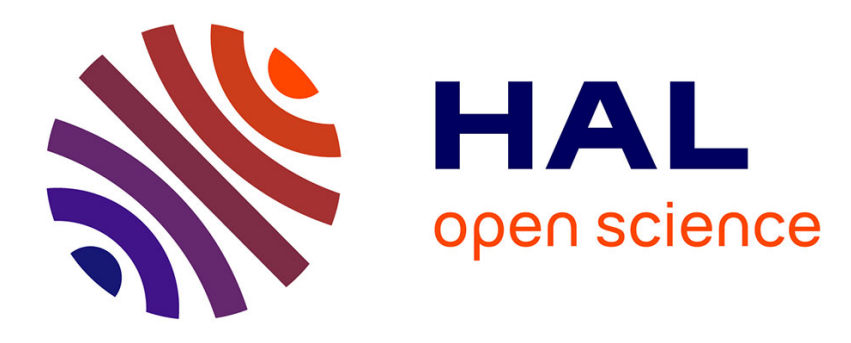

\title{
The Impact of UCITS IV Directive on European Mutual Funds Performance
}

Veasna Khim, Hery Razafitombo

\section{To cite this version:}

Veasna Khim, Hery Razafitombo. The Impact of UCITS IV Directive on European Mutual Funds Performance. 28th Australasian Finance and Banking Conference, Dec 2015, Sydney, Australia. hal01698550

\section{HAL Id: hal-01698550 \\ https://hal.univ-lorraine.fr/hal-01698550}

Submitted on 1 Feb 2018

HAL is a multi-disciplinary open access archive for the deposit and dissemination of scientific research documents, whether they are published or not. The documents may come from teaching and research institutions in France or abroad, or from public or private research centers.
L'archive ouverte pluridisciplinaire HAL, est destinée au dépôt et à la diffusion de documents scientifiques de niveau recherche, publiés ou non, émanant des établissements d'enseignement et de recherche français ou étrangers, des laboratoires publics ou privés. 


\title{
THE IMPACT OF UCITS IV DIRECTIVE ON EUROPEAN MUTUAL FUNDS PERFORMANCE
}

\author{
Veasna KHIM Hery RAZAFITOMBO*
}

Working paper

First version: March 2015 - This version: August 2015

\begin{abstract}
ABTRACT
In this paper we examine the impact of UCITS IV Directive on the performance of European mutual funds. In a sample of 1435 Equity funds from December 2001 to December 2013, we empirically investigate the effects of economies of scale on the relation between size and performance. Using Chen et al. (2004) portfolio approach with various benchmark factors models, we find significant performance improvements according to UCITS IV periods. Using panel regressions with multilevel models, we find that European funds seem to benefit from gains related to size and not face to diseconomies of scale. Nonetheless, some specific characteristics of European fund family structure burden performance. Despite the intention from regulators to provide costless and favorable environment, European fund families are highly diversified and constituted by large number of low-sized members to achieve overall positive spillover effects.
\end{abstract}

Keywords: Performance evaluation, European funds, Economy of scale, UCITS IV JEL Codes: G11, G23

\footnotetext{
* Both authors are Assistant Professors at the University of Lorraine (France) and member of the European Centre for Research in Financial Economics and Business Management (CEREFIGE, EA 3942, University of Lorraine). Mailing adress: CEREFIGE ESM - IAE, University of Lorraine, 1, Rue Augustin Fresnel, F-57073 Cedex 3 Metz France. E-mail addresses: hery.razafitombo@univ-lorraine.fr; veasna.khim@univ-lorraine.fr.

We thank Sandrine Leal Jacob, Vincent Fromentin, Patrick Kouountchou and colleagues from Finance group of CEREFIGE for many thoughtful suggestions and discussions.
} 


\section{CONTENTS}

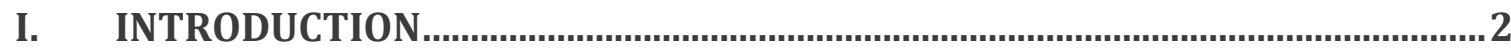

II. THEORETICAL BACKGROUND AND TESTABLE HYPOTHESES

DEVELOPMENT .............................................................................................................. 4

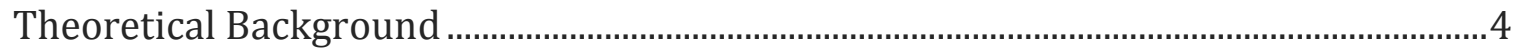

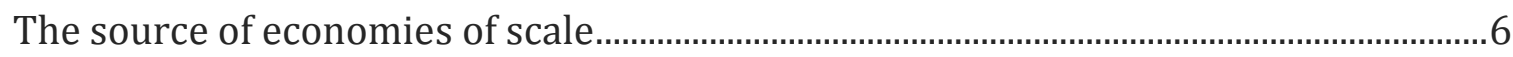

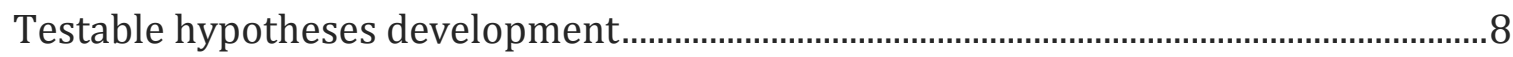

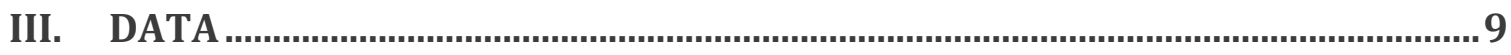

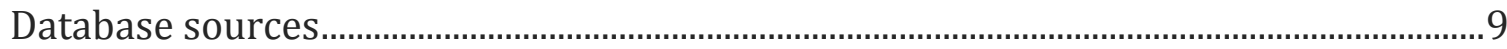

Summary statistics for European fund size by period...................................................... 10

Fund characteristic variables and fund family instruments ............................................12

IV. THE DYNAMICS OF EUROPEAN FUNDS SIZE AND PERFORMANCE: TESTS

BASED ON PORTFOLIO APPROACH .................................................................. 14

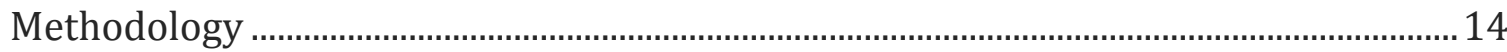

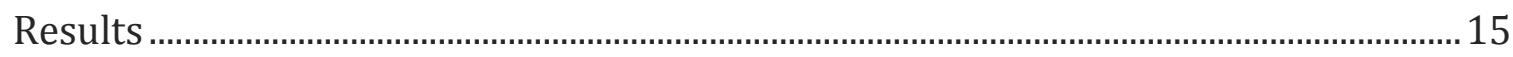

V. THE POTENTIAL SOURCES OF ECONOMIES OF SCALE: TESTS USING

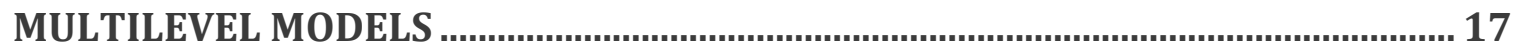

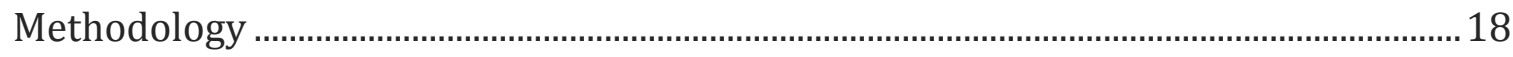

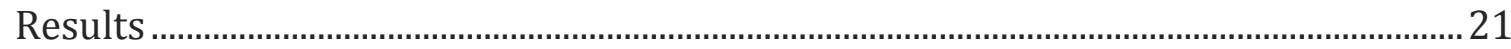

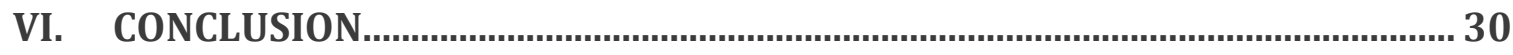

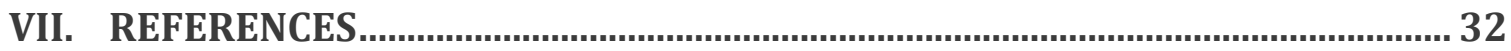

VIII. APPENDIX 


\section{INTRODUCTION}

The aim of this paper is to examine the impact of UCITS IV Directive (Undertakings for the Collective Investment in Transferable Securities, adopted in 2011) on the dynamics of European mutual funds. Since its launch in 1985, the introduction of UCITS Directives has deeply modified the universe of investment funds in Europe. The main purpose is the development of an integrated market and strengthening the competitiveness of European funds through improved coordination between regulators and reinforced investors protection. To this end, UCITS IV Directive is one of the most important bases. UCITS IV Directive differ from the three previous Directives by enabling more cost effective notification procedures and by introducing framework for merging funds. More specifically, it should produce benefits to both investors and managers. To investors, it is expected to provide greater liquidity, more transparency (Key Investor Information Document - KIID) and a more effective management of risks. To managers, with the simplified European passport and the accelerated procedure, it is expected to create cross-border distribution opportunities. It enables access to a larger range of strategies, sophisticated or non -sophisticated funds. It also provides a greater opportunity for structuring funds. Indeed, since UCITS IV Directive, managers have the opportunity to adopt different types of structures according to their own strategies and constraints: a single or conventional strategy fund structure, an umbrella fund structure or a Master and Feeder structure. Further innovations can be added at different levels such as merging funds, depositary, "prime broker", administrators, managers, management companies.

All these developments tend to make the management process more flexible and to render the promotion and the cross-border distribution of European funds more fluid. The costs engaged by investors should be reduced. The merging of funds should be accelerated within European Union. Moreover, this would encourages the development of a much bigger average fund size, conducive to a large and integrated European market with harmonized regulation. Thus, the central hypothesis of our study is based on this fact: UCITS IV Directive significantly change the universe of investment funds in Europe by increasing the average size of funds while facilitating the emergence of economies of scale. Ultimately, this evolution enhances the ability of managers to generate higher risk-adjusted returns. And so, to test this hypothesis, we follow the equilibrium of mutual fund industry approach developed by Berk and Green (2004) and Chen et al. (2004) which introduce the concept of diseconomy of scale in active management portfolio. 
In this perspective, we adopt a two steps analysis. First, in line of the academic literature, we follow the portfolio approach developed by Chen et al. (2004) to examine the direct relation between the dynamic of European funds' size and their performance on the period from December 2001 through December 2013. The aim is to examine if European funds' performance have improved after the transposition of UCITS IV Directive compared to the previous periods and according to funds' size. To that end, we construct five equally weight fund portfolios based on the monthly quartile ranking of their size. We compare the risk adjusted performance of each portfolio for 4 different periods: before crisis (2001-07), during crisis (2007-09), after crisis (2009-11) and after UCITS IV (2011-13). To address the possible existence of heterogeneity in management styles, we use three different performance evaluation models (the 1-factor CAPM, the 3-factors Fama - French and the 4-factors Carhart benchmark models) to estimate risk adjusted performance. Second, we use trans-logarithmic models to test the existing change in the form and the strength of the relation between European funds size and performance before and after UCITS IV Directive adoption. Moreover, as the source of economies of scale can be located at the fund family level, we run panel regressions using multilevel models to identify the family specific characteristics that can explain time-varying change in size and performance relationship. Multilevel models present two main advantages. On the one hand, it allows to test all our hypothesis as a single block. On the other hand, it enables to decompose and to distinguish the part of variance shared by all funds in the family and the own variance of fund member. In our model, we consider the fund performance as a quadratic function of the lagged fund size in which conventional control variables related to fund specific characteristics (flows, age, management fees, redemption fees...) and variables related to family specific characteristics are added. For the family specific variables we run tests with dummy variables and use various Herfindahl-Hirschmann concentration index that can lead information on the extent of diversification and specialization of fund families.

Our empirical analysis relies Lipper-Reuters and Eurofidai databases. We extract UCITS European funds data from Lipper-Reuters database. Our dataset covers 1435 UCITS Equity funds. We extract monthly data from 2001 through 2013. Our family level information are based on over 30000 funds part of considered funds families. We use Eurofidai indices database to extract European factor benchmarks: market returns (RM), factor mimicking portfolios for size (Small minus Big, SMB), book-to-market equity (High minus Low, HML) and one-year momentum in stock returns (MOM). 
Globally, the hypothesis related to the existence of UCITS IV effect is not rejected by the data. With our investigations based on portfolio approach, we find significant performance improvements according to UCITS IV period. Risk adjusted performances measured by alpha coefficients are significant and superior after UCITS IV adoption compared to previous periods. Our investigations based on trans-logarithmic models and multilevel models confirm these issues. We find that European funds seem to benefit from gains related to size and not face to diseconomies of scale. Nonetheless, some specific characteristics of European fund family structure burden performance. Despite the intention from regulators to provide costless and favorable environment, European fund families are highly diversified and constituted by large number of low-sized members to achieve overall positive spillover effects.

The rest of this paper is organized as follows. Section 2 discusses the theoretical and empirical background and summarize our testable hypotheses. Section 3 describes the data used in this study. Section 4 presents the methodology used and the results for tests based on portfolio approach. Section 5 presents the methodology used and the results for tests based on trans-logarithmic models and multilevel models. Section 6 concludes the paper.

\section{Theoretical background and Testable hypotheses Development}

UCITS IV Directives can impact the performance of European mutual funds by following two main ways at fund level and at fund family level. For both, the theoretical background and empirical issues rely the expected improvement of performance to the ability of fund managers to deal with increasing size and to benefit of potential economies of scale.

\section{THEORETICAL BACKGROUND}

The seminal work of Berk and Green (2004) introduces the decreasing returns of scale in rational model of active management portfolio to explain the persistence of performance. Their paper gives a clear scope to understand the relation between size and performance. This economy of scale constraint suppose that performance decreases with size. When funds are news and low sized, active managers are supposed to be able to generate positive and persistent alpha. Investors are supposed to react positively to past returns. They offer new money to funds with positive past returns which increase their size. This rise in turn reduces the efficiency of active management, prompting managers to switch to passive strategies which is less costly to produce. Thus, returns decrease proportionally with inflows. This mechanism is repeated so that the proportion of the active strategies decline in favor of those passive. Ultimately, when optimal size is reached, fund becomes totally dedicated to non-persistent 
passive strategies. In sum, in a rational and competitive market for capital investment, Berk and Green (2004) demonstrate that part of risk adjusted performance are persistent only for short term until funds reached their optimal size. Funds underperformance are valid only for funds that have reached their optimal size. Managers cannot do better than the market to which additional transaction costs still come to reduce returns.

Following Dangl et al. (2008), we can present a model that explicitly rely alpha to decreasing returns to scale:

$$
\alpha_{i}=\theta_{i} w_{i} \epsilon_{i}-\gamma A_{i} w_{i}^{2} \epsilon_{i}^{2}=w_{i} \epsilon_{i}\left(\theta_{i}-\gamma A_{i} w_{i} \epsilon_{i}\right)
$$

Where $\alpha_{i}$ is the Jensen's alpha coefficient; Jensen, $\theta_{i}$ is the manager active skill (exogenous and unobservable); $w_{i}$ is the portfolio weight dedicated to active strategy and $\left(1-w_{i}\right)$ is the portfolio weight dedicated to passive strategy; $\epsilon_{i}$ is a normally distributed noise representing the fund specific risk; $\gamma$ a constant corresponding to diseconomy of scale and $A_{i}$ is the fund size. From equation (1), we propose following relation:

- $\frac{\delta \alpha_{i}}{\delta \theta_{i}}=w_{i} \epsilon_{i}=\sigma_{i}>0$. For the same proportion of asset dedicated to active strategy, a skillful manager will generate superior alpha.

- $\frac{\delta \alpha_{i}}{\delta A_{i}}=-\gamma w_{i}^{2} \epsilon_{i}^{2}=-\gamma \sigma_{i}^{2}<0$. For additional net asset unity, the alpha decreases with the proportion $w_{i}$ dedicated to the active strategy and the constant $\gamma$.

- $\frac{\delta^{2} \alpha_{i}}{\delta^{2} \sigma_{i}^{2}}=-2 \gamma A_{i}<0$. The marginal effect of a specific risk rise decreases faster for larger funds.

- $\frac{\delta^{2} \alpha_{i}}{\delta A_{i} \delta \sigma_{i}}=-2 \sigma_{i}^{2}$. Larger is the fund, smaller is the effect of risk taking on the alpha.

The alpha is an increasing function of manager's skill allowing them to dedicate a larger fund part to active management. Alpha is a decreasing function of size whose magnitude depends on the constant decreasing returns to scale. All things being equal, a most skilled manager can manage a larger fund than a less talented one. This is the fundamental result of Berk and Green (2004) and Dangl et al. (2008) in fund performance evaluation. Fund size is a fundamental observable parameter to estimate the manager's skill. So, it is possible to define the optimal size of fund, i.e. the size beyond which returns cannot be predictable. The perfect capital mobility assumption implies that investors systematically transfer money from bad funds to best ones. Investors respond positively to $\alpha_{i}$ that they cannot perfectly either observe or predict. They are supposed to state beliefs based on past returns and assume that manager's active skill are normally distributed $\theta \sim N\left(a_{i} ; v_{i}\right)$. Under this constraint, manager are assumed to maximize the following function: 


$$
\underset{c_{i}, \sigma_{i}}{\operatorname{Max}} c_{i}(1-F) A_{i}
$$

Where F represent fixed costs. So manager maximizes their revenues under the constraint of compatibility of their incentives with those of investors:

$$
c_{i}=a_{i} \sigma_{i}-\gamma A_{i} \sigma_{i}^{2}
$$

And following feasibility constraints: $c_{i}>0 ; \sigma_{i}>0 ; A_{i}>0$.

To solve this program, we express the equation 3 as a function of $A_{i}$ (fund size). The result is substituted into equation 2 and is derived as a function of $c_{i}$. Thus, return is maximized when:

$$
\frac{c_{i}}{\sigma_{i}}=\frac{a_{i}}{2}
$$

This allows to define the optimal size of the fund:

$$
A_{i}=\frac{a_{i}^{2}}{4 \gamma c_{i}}
$$

On the one hand, the Equation 5 shows that the optimal size of a fund is a positive and quadratic function of the investor's belief on manager's active skill $a_{i}$. This result is consistent with studies dealing with the performance and investment flows. The hypotheses on the distribution function of the belief $\theta_{i}$ play a central role, especially through the impact of fund stars and marketing strategies conducted by fund families. On the other hand, the optimal size of fund is a negative function of fees and the constant term $\gamma$. Once one release the assumption that $\gamma$ is an exogenous constant but rather a random variable, it is possible to assume that the funds which effectively reduce diseconomies of scale are the best performing funds. At the same time, one can assume that those funds succeed in getting the biggest market share. Indeed, we can rely this ascertainment to the aim of the UCITS IV Directive: the Key investor information document which should facilitate performance evaluation (positive effect on $a_{i}$ ) and the European fund passport which must rationalize fund promotion and distribution and then should facilitate economies of scale (negative effect on $\gamma$ ). Therefore, the challenge becomes one of identifying the determinants of $\psi$, i.e. the main sources of diseconomies of scale. This will allow us to understand how concretely UCITS IV Directive may improve fund performance.

\section{THE SOURCE OF ECONOMIES OF SCALE}

In the literature on fund performance evaluation, many studies have highlighted the potential sources of decreasing returns of scale. Gruber (1996) stated that the aim of active management is mainly to have "good ideas" of investment, but the value of these "good ideas" 
progressively deteriorated once diffused on a more or less efficient market. He explained the fund underperformance and concluded that skillful managers are whom permanently find "good ideas". Thereby, the issues of decreasing returns of scale tied up the kernel of the research and the detection of best investment opportunities.

Recently, Pastor and Stambaugh (2014) show that the extent of diseconomies of scale is not constant. It mainly varies depending on the active management size compared to the size of passive management in the fund industry. When the share of active management is small, due to less competition, it is easier for managers to find good investment opportunities. Investors respond positively by increasing investment flows to their destinations which automatically increases the size of the active management compared to the overall fund industry. Through this mechanism, the difficulty to find other investment opportunities, and thus the extent of diseconomies of scale, increases as competition intensifies among managers and reduce the "stock" good opportunities. Consequently, this deteriorates fund performances at the same pace as the growth of active management in the industry. This mechanism can extended to family fund as a coordinated entities. Massa (1998) attempts to explain the growth of fund industry. He shows that there are too much funds on the market to be justified by the only investors need for diversification. Khorana and Servaes $(1999,2012)$ indicate that the launching of new funds by families responds to differentiation strategies which aim to segment fund market. This leads to reduce competition by narrowing prices and so for performance. Massa (2003) and Gaspar et al. (2007) show that fund families make an arbitrage amongst «proliferation fund strategies» and an improvement performance of existing funds. Particularly, families which dominate the market favor some of their funds by cross-fund subsidization. These cross-fund subsidization strategies aim to facilitate spillover effects for fund stars. The standing of fund stars will benefit other less prestigious fund members [Del Guercio et al. (2002, 2008), Wilcox (2003), Nanda et al. (2004, 2009), Kosowsky et al. (2006), Kacperczyk et al. $(2005,2008)]$.

On investors' side, it was largely shown that they are more sensitive and overreact to good performance than for bad performance (Sirri and Tufano, 1998). This convex form of the relation between performance and flows impacts the competition on the fund market. It encourages fund families to adopt spillover strategies. So, they do not penalize funds which display poor performance Lettau (1999), Capon et al. (1998), Barber et al. (2000), Goetzman and Peles (1997)]. Herein, the UCITS IV Directive requirements with the key investor information document and the European fund passport are advantageous to large fund families. 
Let's recall that the aim is to rationalize European funds offers by splitting the industry around a few number of large fund families. This industry concentration reinforces the power and the control of fund industry by large families. Thus, it would reduce the competition intensity as far as they have some organizational characteristics and governance structure. So they can more efficiently manage the effects of economies of scale.

Chen et al. (2004) investigate the impact of liquidity, hierarchy and transaction costs. They show that fund families adopt organizational structures which allow them to optimize their information systems and to manage common skills. More recently, Chen et al. (2013) show that internal funds member of the family display better performance than external funds promoting by the same management company. They explained this results by the fact that internal funds share technologies and use the same governance model to coordinate managers. For fund family associated to bank company, Massa et al. (2007) show that the bank lending activities impact the assets choice and allocation of their own fund managers. They conclude that the sharing of information and technologies is not limited to the asset management activity. Fund members of large family share more large commons skills such as ideas, information systems processes, technologies, trading desks, legal counselors, outside experts, macroeconomic anticipations and microeconomic opinions... (Brown and Yu (2014)).

\section{TESTABLE HyPOTHESES DEVELOPMENT}

Following Berk and Green (2004), the relation between size and the manager's ability to generate positive alpha depends on the following conditions:

- Alpha decrease with inflows (increasing size of fund). There is an active management skill that is submit to returns decreasing of scale.

- Alpha is not directly observable by investors. They can observe fund size and age.

- There is a perfect mobility of capital, fund size can increase until performance become unpredictable.

It appears that UCITS IV Directives should facilitate the first and the third conditions. The KIID and all requirements aiming transparency are used to facilitate the perfect mobility of capital. The UCITS passport attempts to generate economies of scale by allowing choices in terms of structure for funds grouping. Consequently, this should increase steadily fund size. Nevertheless, all these additional resources can have contradictory impacts on performance. On the one hand, managers can enhance their diversification scope but they have also to face an increasing transaction and hierarchy costs. On the other hand, there are expectations about synergy (sharing commons skills, costs reductions...) as a result of the adoption of UCITS 
structure. So performance can increase or decrease depending on the dominant effects. Herein, this is central point of our study. The issue is to investigate if UCITS IV Directive realize totally its aim. From this, one main question raises. First, do European funds display economies of scale since the adoption of UCITS IV Directive? This question lead to our two main testable hypotheses:

H1: Due to the existence of economies of scale, European funds display better performance on the period after the adoption of UCITS IV Directive compared to previous periods.

H2: The strength of economies of scale depends on the main characteristics of European fund families.

To test these hypotheses, we follow the equilibrium of mutual fund industry approach developed by Berk and Green (2004) and Chen et al. (2004) which permits to test the existence of positive and persistent alpha by taking into account that "performance generation process" is subject to costs related to fund size.

\section{DATA}

\section{DATABASE SOURCES}

Our study use two main sources: Lipper-Reuters and Eurofidai indices databases. We extract UCITS European funds data from Lipper-Reuters database. Our dataset covers 1435 UCITS Equity funds. We extract monthly data from 2001 through 2013. Our family level information are based on over 30000 funds part of considered funds families. For all funds we collect data related to net asset value (TNA), size (at fund and family level), age, management and redemption fees, Lipper classification category (at fund and family level). To deal with usual biases, our database include live, dead, new and merge funds covering all period sample. We use Eurofidai indices database to extract European factor benchmarks: market returns (RM, MSCI Europe), 1-month Euribor (RF, risk free rate), factor mimicking portfolios for size (Small minus Big, SMB), book-to-market equity (High minus Low, HML) and one-year momentum in stock returns (MOM). For all our empirical tests, we split our sample in 4 sub-periods:

- P1: Before crisis - from December 2001 to September 2007

- P2: During crisis - from September 2007 to February 2009

- P3: After crisis - from March 2009 to June 2011

- P4: After UCITS IV - from July 2011 to December 2013. 


\section{SUMMARY STATISTICS FOR EUROPEAN FUND SIZE BY PERIOD}

Hereafter some summary statistics related to our dataset. Table 1 reports summary statistics related to fund size per period. It indicates that the number of funds has doubled between 2001 through 2013, from 738 to 1400. The year 2007-08 related to crisis period has not impeded this development, but basically impacted fund values. From 2001 to 2007, the total asset outstanding that was multiplied by 2.5 is almost melted to recover its original value, around 200 billion $€$ in March 2008. The funds' total net asset increased by around 50 percent and reach 241 billion $€$ at the end of 2013.

Table 1: Descriptive statistics for European fund size by period

\begin{tabular}{|l|rr|rr|rr|r|r|}
\hline & \multicolumn{2}{|c|}{$\begin{array}{l}\mathbf{1 2 . 2 0 0 1 - 0 9 . 2 0 0 7} \\
\text { Before crisis (P1) }\end{array}$} & \multicolumn{2}{|c|}{$\begin{array}{c}\mathbf{1 0 . 2 0 0 7 - 0 2 . 2 0 0 9} \\
\text { During Crise (P2) }\end{array}$} & \multicolumn{2}{|c|}{$\begin{array}{c}\mathbf{0 3 . 2 0 0 9} \mathbf{- 0 6 . 2 0 1 1} \\
\text { After Crisis (P3) }\end{array}$} & $\begin{array}{c}\mathbf{0 7 . 2 0 1 1}-\mathbf{1 2 . 2 0 1 3} \\
\text { After UCITS IV (P4) }\end{array}$ \\
\cline { 2 - 9 } & Number & Total TNA & Number & Total TNA & Number & Total TNA & Number & Total TNA \\
\hline Mean & 1055 & 284037 & 1494 & 341923 & 1517 & 275324 & 1399 & 281187 \\
Median & 1042 & 233949 & 1504 & 348335 & 1529 & 279107 & 1403 & 268802 \\
Standard deviation & 180 & 109486 & 58 & 93128 & 44 & 25713 & 25 & 37794 \\
Plage & 648 & 364135 & 174 & 287616 & 138 & 105896 & 102 & 130778 \\
Minimum & 738 & 150423 & 1391 & 202262 & 1435 & 201804 & 1336 & 237349 \\
Maximum & 1386 & 514558 & 1565 & 489878 & 1573 & 307700 & 1438 & 368127 \\
\hline
\end{tabular}

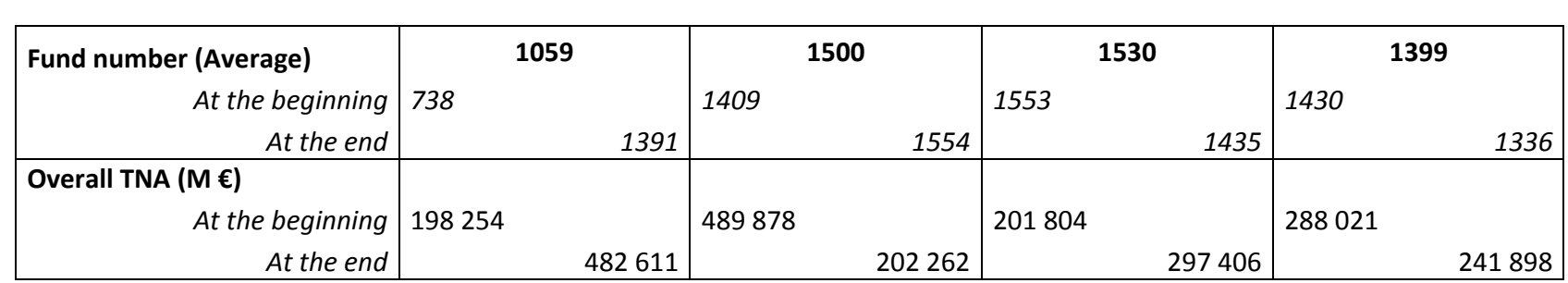

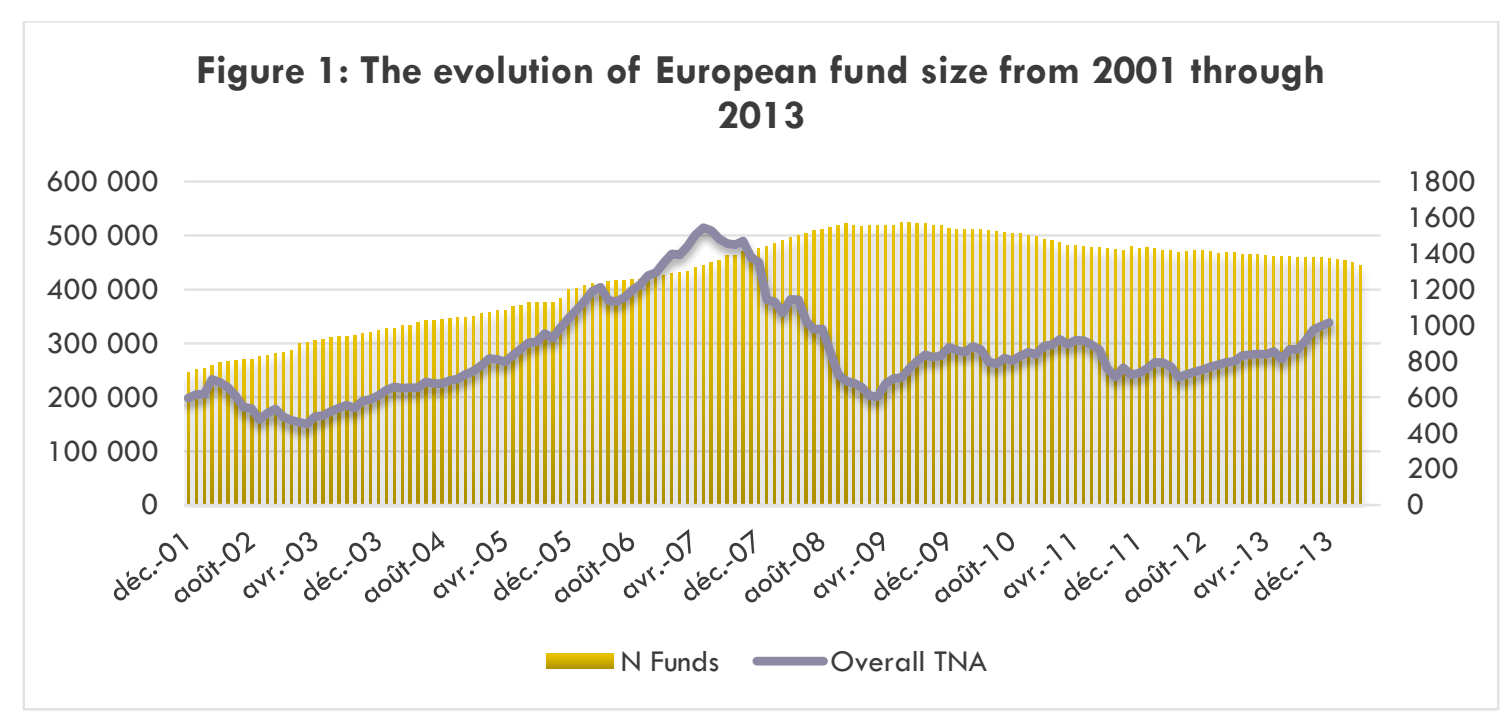

Figure 1 clearly illustrates this evolution. This contrasting trend probably can be explained in part by the after financial crisis upward trend and the reversion to mean effect. It also suggests that the UCITS IV Directive may have played an important role. Indeed, UCITS IV 
Directive seems to play a catalytic role in the creation and structuring of funds and then have stabilized funds' production.

\begin{tabular}{|c|c|c|c|c|c|c|c|c|c|c|c|c|}
\hline & \multicolumn{3}{|c|}{$\begin{array}{l}\text { 12.2001- } 09.2007 \\
\text { Before crisis (P1) }\end{array}$} & \multicolumn{3}{|c|}{$\begin{array}{l}10.2007-02.2009 \\
\text { During crisis }(\mathrm{P} 2)\end{array}$} & \multicolumn{3}{|c|}{$\begin{array}{c}03.2009-06.2011 \\
\text { After crisis (P3) }\end{array}$} & \multicolumn{3}{|c|}{$\begin{array}{l}07.2011 \text { - } 12.2013 \\
\text { After UCITS IV (P4) }\end{array}$} \\
\hline & Q1 & Q2 & Q3 & Q1 & Q2 & Q3 & Q1 & Q2 & Q3 & Q1 & Q2 & Q3 \\
\hline Mean & 20,73 & 64,85 & 231,95 & 18,55 & 61,23 & 211,92 & 17,24 & 52,07 & 166,47 & 21,99 & 68,56 & 210,80 \\
\hline Median & 19,05 & 57,35 & 216,74 & 18,31 & 60,07 & 207,09 & 16,72 & 51,36 & 166,84 & 21,08 & 62,15 & 202,48 \\
\hline Standard deviation & 7,43 & 21,01 & 79,48 & 5,94 & 21,49 & 69,93 & 3,32 & 9,49 & 16,94 & 3,80 & 15,70 & 36,94 \\
\hline Plage & 26,52 & 74,26 & 259,41 & 19,44 & 66,02 & 226,74 & 12,34 & 34,23 & 70,77 & 13,28 & 49,13 & 131,44 \\
\hline Minimum & 10,93 & 38,38 & 115,20 & 11,13 & 33,34 & 119,23 & 11,24 & 34,36 & 121,05 & 17,33 & 52,40 & 164,12 \\
\hline Maximum & 37,45 & 112,64 & 374,61 & 30,57 & 99,36 & 345,98 & 23,57 & 68,60 & 191,82 & 30,62 & 101,53 & 295,55 \\
\hline
\end{tabular}

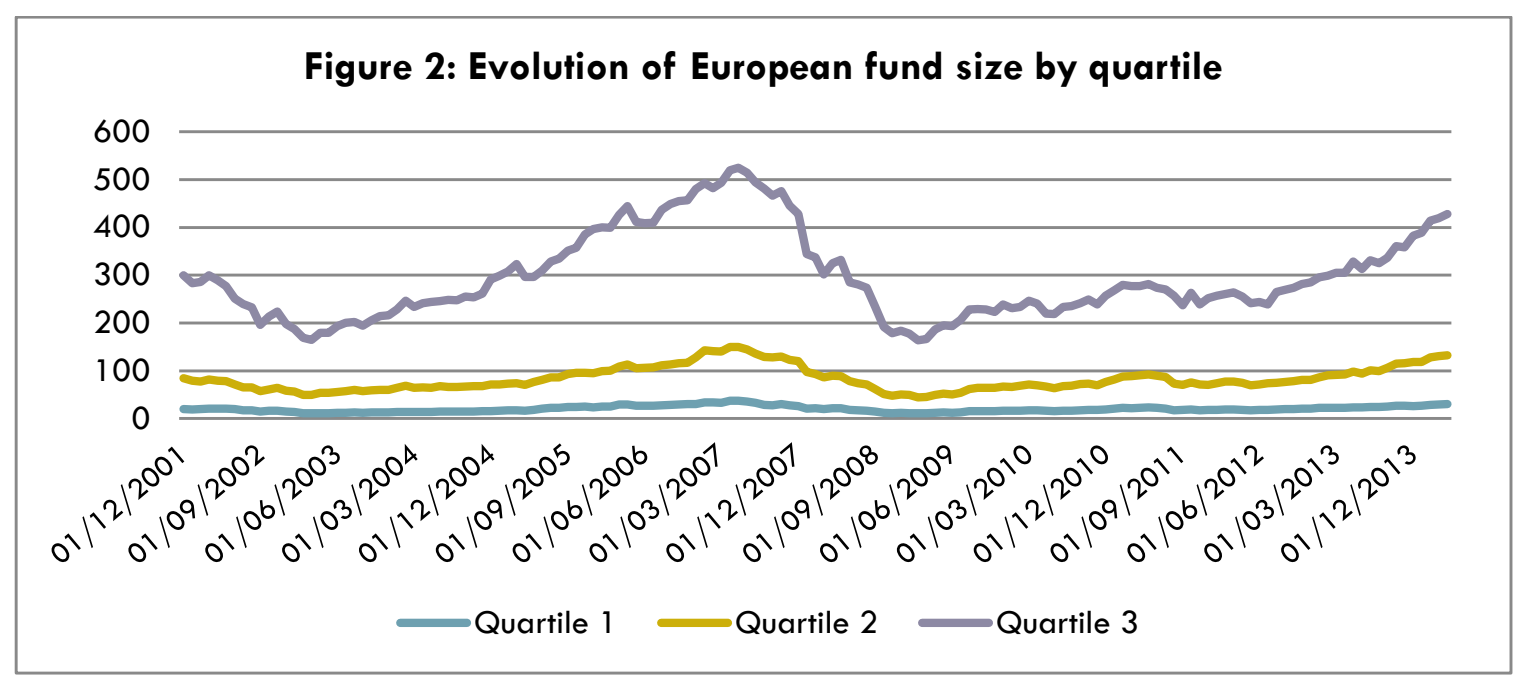

Table 2 and Figure 2 give a more clear indication of the dynamics of the European fund size by period and by quartile. These illustrations allow to visualize the differences between P1 - P2 periods (before and during the crisis) and P3 - P4 periods (after-crisis and after UCITS IV adoption). While the central values (mean and median) are relatively similar for the four periods, there is a shrinking of the fund size values. Standard deviations within segments are steadily reduced with time. The small funds (Q1) show respectively standard deviations of 7.43 and 5.94 for P1 and P2. The standard deviations are 3.32 and 3.8 for the periods P3 and P4. The same trend is observed for large funds (Q3). The standard deviations are respectively 79.48 and 69.93 for P1 and P2. They are reduced to 16.94 and 36.94 to P3 to P4. These funds size spreads are also observed with the reduction of the fund size range values. For small funds, the differences between the minimum and maximum sizes are 26.52 for P1 and 19.44 for P2. These differences are reduced for large funds to move from 12.34 for P3 and 13.28 for P4. These range 
reductions on each segment once again open the debate about the role of UCITS IV Directive. Indeed, alongside possible cyclical effect, this may indicate an improvement in size and economies of scale management by fund managers.

\section{FUND CHARACTERISTIC VARIABLES AND FUND FAMILY INSTRUMENTS}

In our tests we use two groups of variables. A first group formed by usual fund specific instruments such as lagged fund size, flow, age, management and redemption fees. The second group of variables is formed by family specific instruments which give information about their organizational structure. We use variables to assess potential sources of economies of scale through e.g. the extent of geographic diversification and/or the degree of specialization of the fund families such as:

- Fund family size (LogFamSize)

- Number of funds member of the family (LogNFam)

- Large family - up to 20 fund members (Large_20, dummy variable)

- Large Equity Family : up to 20 Equity funds member (EQ_Large_20, dummy variable)

- Family concentration depending on fund member's weight (TNA) within the family (HHI_TNA_F $)^{1}$. A value close to 1 indicates the presence of « fund stars », that is a small number of member with a greater contribution to the family. A value close to 0 indicates balanced contributions for each fund within the family.

- Family concentration depending on Lipper classes size (HHI_TNA_LC). This variable measures the family degree of specialization according to the size of different asset classes of all fund in the family. A value close to 1 indicates a highly specialized family which implies a better expertise and understanding of resources related to the considered asset classes. A value close to 0 indicates that family are diversified in terms of asset classes' allocation.

- Family concentration depending on the number of asset classes (HHI_N_LC). This variable measures the diversity of product range covered by the family. A value close to 1 indicates a family specialized and promoting few range of fund classes. A value close to 0 indicates that family covered a large range of fund classes.

- Family concentration depending on fund members' domicile (HHI_D). This variable measures the geographical presence of the family. A value close to 1 indicates a reduced number of domicile location. A value close to 0 indicates a more extensive geographic network. 
- Family concentration depending on Equity fund members' domicile (EQ_HHI_D). This variable measures the geographical presence of the family for the only Equity fund members. A value close to $1(0)$ indicates a large Equity funds less (more) extensive equity funds' domicile.

\begin{tabular}{|c|c|c|c|c|c|c|c|c|c|}
\hline \multirow[t]{2}{*}{ Label } & \multirow[t]{2}{*}{ Variable } & \multicolumn{2}{|c|}{$\begin{array}{l}\text { 12.2001-09.2007 } \\
\text { Before crisis }(\mathrm{P} 1)\end{array}$} & \multicolumn{2}{|c|}{$\begin{array}{l}\text { 10.2007-02.2009 } \\
\text { During crisis (P2) }\end{array}$} & \multicolumn{2}{|c|}{$\begin{array}{l}03.2009-6.2011 \\
\text { After crisis (P3) }\end{array}$} & \multicolumn{2}{|c|}{$\begin{array}{l}07.2011-12.2013 \\
\text { After UCITS (P4) }\end{array}$} \\
\hline & & Mean & Std & Mean & Std & Mean & Std & Mean & Std \\
\hline Number of fund members & N_Fam & 56 & 116 & 61 & 132 & 58 & 126 & 52 & 108 \\
\hline Family fund size (M€) & FamSize & 9188 & 21878 & 8523 & 21279 & 8208 & 20642 & 8149 & 19871 \\
\hline Number of Equity fund members & N Fam EQ & 17 & 25 & 18 & 27 & 16 & 25 & 14 & 22 \\
\hline Family up to 20 members & Large 20 & 0,476 & N/A & 0,477 & N/A & 0,485 & N/A & 0,474 & N/A \\
\hline Family up to 20 Equity fund members & EQ Large 20 & 0,273 & N/A & 0,258 & N/A & 0,232 & N/A & 0,195 & N/A \\
\hline $\begin{array}{l}\text { Herfindahl-Hirshmann concentration } \\
\text { index depending on fund size }\end{array}$ & HHI_TNA_F & 0,213 & 0,214 & 0,228 & 0,223 & 0,228 & 0,226 & 0,234 & 0,233 \\
\hline $\begin{array}{l}\text { Herfindahl-Hirshmann concentration } \\
\text { index depending on Lipper class } \\
\text { numbers }\end{array}$ & HHI_N_LC & 0,178 & 0,186 & 0,179 & 0,188 & 0,186 & 0,199 & 0,189 & 0,202 \\
\hline $\begin{array}{l}\text { Herfindahl-Hirshmann concentration } \\
\text { index depending on Lipper class size }\end{array}$ & HHI_TNA_LC & 0,281 & 0,218 & 0,301 & 0,226 & 0,297 & 0,23 & 0,296 & 0,234 \\
\hline $\begin{array}{l}\text { Herfindahl-Hirshmann concentration } \\
\text { index depending on the number of fund } \\
\text { domicile }\end{array}$ & HHI_D & 0,845 & 0,228 & 0,843 & 0,231 & 0,852 & 0,227 & 0,866 & 0,221 \\
\hline $\begin{array}{l}\text { Herfindahl-Hirshmann concentration } \\
\text { index depending on the number of } \\
\text { Equity fund domicile }\end{array}$ & EQ_HHI_D & 0,874 & 0,214 & 0,869 & 0,22 & 0,875 & 0,217 & 0,884 & 0,213 \\
\hline
\end{tabular}

Table 3 above reports descriptive statistics related to fund characteristic variables and fund family instruments. This reveals some specific properties about equity European funds in our dataset. First, we do not observe important difference in terms of evolution for the 4 considered periods. This finding suggests that UCITS IV Directives adoption, contrary to what is expected, has no major effect on the structure and the size of European funds. Second, European fund families are constituted by groups composed of a large number of members. Families are on average composed of 56 members with an average size around 9 billion $€$. Standard deviations of fund numbers within families are on average superior to 100. This indicates that funds in our dataset is made up of the two extremes. Many individual funds and families can have more than 100 members. On average around 48 percent of families have more than 20 funds. And 27 percent are composed by up to 20 equity funds. In terms of asset classes, families are significantly diversified. The concentration index depending on the size of fund members are 
about 22 percent. The Herfindahl-Hirschmann indexes depending on the number and the size of Lipper class are on average about 18 percent and 29 percent, respectively. On the contrary, concentration indexes depending on the number of domiciliation for all funds and for only equity funds are high, about 85 percent and 87 percent respectively.

\section{THE DYNAMICS OF EUROPEAN FUNDS SIZE AND PERFORMANCE: TESTS BASED ON PORTFOLIO APPROACH}

Following Chen et al. (2004) we examine the existence of significant relation between European funds size and performance for 4 period from 2001 through 2013. These exploratory empirical investigations are based on our two main hypotheses.

H1a - On the existence of UCITS IV effects: Risk adjusted performances for period after UCITS IV adoption (P4) are superior to those of previous periods (P1, P2 and P3).

H2a - On the existence economies of scale: For the period after UCITS IV adoption (P4), large funds improve their performance compared to previous periods and to small funds.

\section{METHODOLOGY}

In all our tests, we use consecutively three main performance evaluation models: the 1-factor CAPM, the Fama-French 3-factors and the 4-factors Carhart benchmark models.

- $\quad$ The 1-factor CAPM model:

$$
R_{i, t}=\alpha_{i}+\beta_{0, i} R M_{t}+\varepsilon_{i, t}
$$

- 3-factors Fama-French model:

$$
R_{i, t}=\alpha_{i}+\beta_{0, i} R M_{t}+\beta_{1, i} S M B_{t}+\beta_{2, i} H M L_{t}+\varepsilon_{i, t}
$$

- 4-factors Carhart model:

$$
R_{i, t}=\alpha_{i}+\beta_{0, i} R M_{t}+\beta_{1, i} S M B_{t}+\beta_{2, i} H M L_{t}+\beta_{3, i} M O M_{t}+\varepsilon_{i, t}
$$

These three models permit to estimate the Jensen's alpha coefficients which represent the risk adjusted performance taking into account the heterogeneity of style related to funds. Thus, different risk factors are considered: the only market risk (RM) for the one factor model, the factor mimicking portfolios for size (Small minus Big, SMB), the book-to-market equity (High minus Low, HML) for the 3-factors Fama-French model and the added one-year momentum in stock returns (MOM) for the 4-factors Carhart model. Summary statistics related to these factors are reported in Appendix 1. According to Chen et al. (2004) methodology, we carry out cross-sectional regressions on European funds return series. The approach consists in 
constructing 5 equally weighted portfolios based on a segmented funds' universe into 4 groups in accordance with the quartile ranking of their size.

- Portfolio All (PTF ALL) - Equally weighted portfolio including all funds in our dataset

- Portfolio 1 (PTF1) - Equally weighted portfolio including small funds with size inferior to quartile $1,[0, \mathrm{Q} 1[$;

- Portfolio 2 (PTF2) - Equally weighted portfolio including funds with size comprise between quartile 1 and quartile 2, [Q1, Q2 [;

- Portfolio 3 (PTF3) - Equally weighted portfolio including medium funds with size comprise between median and quartile 3, [Q2, Q3[ ;

- Portfolio 4 (PTF4) - Equally weighted portfolio including large funds with size superior to quartile 3, [Q3, 100[.

\section{Results}

Beforehand, we conducted a direct comparison of performance and risk for the 5 different portfolios. Table 4 below shows the main results of this analysis. The important point to observe is the inversion of performance between the five portfolios for the period after UCITS IV (P4) compared to the three previous periods (P1, P2 and P3). Small fund portfolios (PTF1 and PTF2) display higher performance for periods P1, P2 and P3 and significantly superior than those of large fund portfolios (PTF3 and PTF4). This observation is inverted for the period P4. Large fund portfolios (PTF3 and PTF4) present higher performance than PTF1 and PTF2. This reversal seems to confirm our previous findings and our research hypothesis according to which the UCITS IV period is combined with better expertise and control for size and performance management by European funds.

Table 4: Portfolio approach on the fund size and performance.

\begin{tabular}{|l|ccccc|ccccc|}
\hline & \multicolumn{3}{|c}{$\mathbf{1 2 . 2 0 0 1 - 0 9 . 2 0 0 7}$ Before crisis (P1) } & \multicolumn{3}{c|}{$\mathbf{1 0 . 2 0 0 7}-\mathbf{0 2 . 2 0 0 9}$ During crisis (P2) } \\
\cline { 2 - 11 } & PTF ALL & PTF1 & PTF2 & PTF3 & PTF4 & PTF ALL & PTF1 & PTF2 & PTF3 & PTF4 \\
\hline Performance* & 0,039 & 0,032 & 0,052 & 0,032 & 0,031 & $-0,412$ & $-0,408$ & $-0,400$ & $-0,404$ & $-0,429$ \\
Risk* & 0,143 & 0,143 & 0,142 & 0,145 & 0,149 & 0,193 & 0,190 & 0,193 & 0,200 & 0,189 \\
Sharpe ratio* & 0,271 & 0,222 & 0,369 & 0,218 & 0,211 & $-2,132$ & $-2,141$ & $-2,070$ & $-2,019$ & $-2,266$ \\
Kurstosis & 1,997 & 1,840 & 2,027 & 1,865 & 1,539 & $-0,251$ & 0,016 & $-0,296$ & $-0,456$ & $-0,410$ \\
Skewness & $-1,128$ & $-1,095$ & $-1,137$ & $-0,991$ & $-1,013$ & $-0,703$ & $-0,672$ & $-0,581$ & $-0,527$ & $-0,773$ \\
Plage & 0,234 & 0,229 & 0,232 & 0,242 & 0,237 & 0,198 & 0,205 & 0,208 & 0,208 & 0,183 \\
Minimum & $-0,142$ & $-0,139$ & $-0,139$ & $-0,145$ & $-0,145$ & $-0,163$ & $-0,164$ & $-0,160$ & $-0,160$ & $-0,161$ \\
Maximum & 0,092 & 0,090 & 0,093 & 0,096 & 0,092 & 0,034 & 0,041 & 0,048 & 0,048 & 0,022 \\
\hline
\end{tabular}

* Annualized 
Table 4: Portfolio approach on the fund size and performance (continued)

\begin{tabular}{|l|ccccc|ccccc|}
\hline & \multicolumn{3}{|c|}{$\mathbf{0 3 . 2 0 0 9}-\mathbf{0 6 . 2 0 1 1}$ After crisis (P3) } & \multicolumn{3}{c|}{$\mathbf{0 7 . 2 0 1 1}-\mathbf{1 2 . 2 0 1 3}$ After UCITS IV (P4) } \\
\cline { 2 - 10 } & PTF ALL & PTF1 & PTF2 & PTF3 & PTF4 & PTF ALL & PTF1 & PTF2 & PTF3 & PTF4 \\
\hline Performance* & 0,152 & 0,166 & 0,159 & 0,144 & 0,138 & 0,071 & 0,048 & 0,073 & 0,085 & 0,080 \\
Risk* & 0,133 & 0,136 & 0,134 & 0,138 & 0,139 & 0,133 & 0,135 & 0,133 & 0,131 & 0,133 \\
Sharpe ratio* & 1,144 & 1,219 & 1,187 & 1,041 & 0,989 & 0,532 & 0,355 & 0,549 & 0,651 & 0,600 \\
Kurstosis & 0,605 & 0,790 & 0,267 & 1,069 & 0,896 & 2,361 & 2,321 & 2,436 & 2,139 & 2,495 \\
Skewness & 0,563 & 0,579 & 0,479 & 0,619 & 0,502 & $-1,282$ & $-1,307$ & $-1,277$ & $-1,215$ & $-1,290$ \\
Plage & 0,176 & 0,180 & 0,172 & 0,185 & 0,188 & 0,188 & 0,187 & 0,189 & 0,184 & 0,190 \\
Minimum & $-0,058$ & $-0,058$ & $-0,057$ & $-0,061$ & $-0,065$ & $-0,117$ & $-0,120$ & $-0,117$ & $-0,111$ & $-0,116$ \\
Maximum & 0,118 & 0,122 & 0,114 & 0,125 & 0,123 & 0,071 & 0,067 & 0,072 & 0,073 & 0,075 \\
\hline
\end{tabular}

* Annualized

The main results of our empirical investigations based the three performance evaluation models allows to go further on this finding insofar as it is based on the extraction of alpha coefficients which measure risk-adjusted performance associated with active management. Table 5 below reports results of our tests.

First of all, we obtain a good quality of regressions. The adjusted $\mathrm{R}^{2}$ are high, around $90 \%$ on average. For all our tests, the alpha coefficients are negative and highly significant. The values of alpha coefficients are slightly different for the three models. These results are consistent with similar studies on European fund performance (Otten and Bams (2002), Banegas (2013), VidalGarcía Javier (2013)).

Regarding to our research hypotheses, H1a related to the existence of UCITS IV effects is not rejected by the data. The alpha coefficients are significant and different for the four periods. Referring to the results of the 4-factors Carhart model, alpha coefficients are around $2 \%$ for the full sample, $-2.7 \%$ for $\mathrm{P} 1,-4.1 \%$ for $\mathrm{P} 2,-1 \%$ for $\mathrm{P} 3$ and $-0.4 \%$ for $\mathrm{P} 4$. The performance gains between after UCITS IV period and previous periods are on the order of $2.3 \%, 3.7 \%$ and $0.6 \%$ respectively. A gain of $1.5 \%$ if one refers to the average of full sample. As for hypothesis H2a on the existence of economies of scale, the results are mixed. Globally, with regard to alphas obtained for the full sample, the differences are very small and non-significant for all four portfolios based on different quartile. The same results are observed for alphas estimated on all periods, except for the small fund portfolio (PTF1) for P2. The differences are very small to permit a significant scope for comment. Thus at this stage, the assumption that the UCITS IV Directive positively affects the performance of European funds is not rejected by the data even if one can conceive here that part of this evolution can be explained by economic recovery trend. Especially the fact that the three periods (P1, P3 and P4) correspond to after specific financial 
crisis, with significant performance gaps, reinforces this conclusion of positive impacts and improvement in size and performance management after UCITS IV.

\begin{tabular}{|c|c|c|c|c|c|c|c|c|c|c|c|}
\hline \multirow{2}{*}{\multicolumn{2}{|c|}{ Panel A : CAPM }} & \multicolumn{2}{|c|}{ Full sample } & \multicolumn{2}{|c|}{ P1 } & \multicolumn{2}{|c|}{ P2 } & \multicolumn{2}{|c|}{ P3 } & \multicolumn{2}{|c|}{ P4 } \\
\hline & & Alpha & Adj $R^{2}$ & Alpha & Adj $R^{2}$ & Alpha & Adj $R^{2}$ & & & Alpha & Adj $R^{2}$ \\
\hline \multirow[t]{2}{*}{ PTF All } & Coef. & $-0,0206$ & 0,890 & $-0,027$ & 0,938 & $-0,041$ & 0,862 & $-0,009$ & 0,904 & $-0,005$ & 0,942 \\
\hline & $t$-stat & $-14,752$ & & $-20,931$ & & $-6,102$ & & $-3,445$ & & $-2,563$ & \\
\hline \multirow[t]{2}{*}{ PTF1 } & Coef. & $-0,0210$ & 0,871 & $-0,028$ & 0,894 & $-0,041$ & 0,826 & $-0,009$ & 0,910 & $-0,006$ & 0,912 \\
\hline & $t$-stat & $-13,850$ & & $-16,297$ & & $-5,618$ & & $-3,457$ & & $-2,881$ & \\
\hline \multirow[t]{2}{*}{ PTF2 } & Coef. & $-0,020$ & 0,891 & $-0,026$ & 0,937 & $-0,039$ & 0,865 & $-0,007$ & 0,907 & $-0,004$ & 0,946 \\
\hline & $t$-stat & $-14,302$ & & $-20,105$ & & $-5,879$ & & $-2,843$ & & $-2,464$ & \\
\hline \multirow[t]{2}{*}{ PTF3 } & Coef. & $-0,021$ & 0,872 & $-0,028$ & 0,922 & $-0,037$ & 0,902 & $-0,010$ & 0,790 & $-0,003$ & 0,953 \\
\hline & $t$-stat & $-13,567$ & & $-18,664$ & & $-6,435$ & & $-2,623$ & & $-2,119$ & \\
\hline \multirow[t]{2}{*}{ PTF4 } & Coef. & $-0,021$ & 0,865 & $-0,028$ & 0,925 & $-0,037$ & 0,893 & $-0,009$ & 0,783 & $-0,004$ & 0,954 \\
\hline & $t$-stat & $-13,393$ & & $-18,922$ & & $-6,124$ & & $-2,320$ & & $-2,472$ & \\
\hline
\end{tabular}

\begin{tabular}{|c|c|c|c|c|c|c|c|c|c|c|c|}
\hline \multirow{2}{*}{\multicolumn{2}{|c|}{$\begin{array}{l}\text { Panel B : Fama - } \\
\text { French model }\end{array}$}} & \multirow{2}{*}{$\begin{array}{l}\text { Full sample } \\
\text { Alpha }\end{array}$} & \multirow[b]{2}{*}{ Adj $R^{2}$} & \multicolumn{2}{|c|}{ P1 } & \multicolumn{2}{|c|}{ P2 } & \multicolumn{2}{|c|}{ P3 } & \multicolumn{2}{|c|}{ P4 } \\
\hline & & & & Alpha & Adj $R^{2}$ & Alpha & Adj $R^{2}$ & Alpha & Adj $R^{2}$ & Alpha & Adj $R^{2}$ \\
\hline \multirow[t]{2}{*}{ PTF All } & Coef. & $-0,021$ & 0,898 & $-0,027$ & 0,947 & $-0,044$ & 0,927 & $-0,009$ & 0,903 & $-0,005$ & 0,957 \\
\hline & $t$-stat & $-15,107$ & & $-21,999$ & & $-8,956$ & & $-3,393$ & & $-2,984$ & \\
\hline \multirow[t]{2}{*}{ PTF1 } & Coef. & $-0,021$ & 0,883 & $-0,027$ & 0,913 & $-0,046$ & 0,931 & $-0,011$ & 0,914 & $-0,007$ & 0,941 \\
\hline & $t$-stat & $-14,366$ & & $-17,296$ & & $-9,686$ & & $-3,969$ & & $-3,484$ & \\
\hline \multirow[t]{2}{*}{ PTF2 } & Coef. & $-0,020$ & 0,902 & $-0,026$ & 0,951 & $-0,042$ & 0,921 & $-0,008$ & 0,904 & $-0,004$ & 0,962 \\
\hline & $t$-stat & $-14,839$ & & $-21,936$ & & $-8,170$ & & $-2,929$ & & $-2,957$ & \\
\hline \multirow[t]{2}{*}{ PTF3 } & Coef. & $-0,021$ & 0,881 & $-0,027$ & 0,929 & $-0,040$ & 0,945 & $-0,010$ & 0,794 & $-0,004$ & 0,962 \\
\hline & $t$-stat & $-13,858$ & & $-19,106$ & & $-9,114$ & & $-2,213$ & & $-2,433$ & \\
\hline \multirow[t]{2}{*}{ PTF4 } & Coef. & $-0,021$ & 0,867 & $-0,028$ & 0,929 & $-0,040$ & 0,940 & $-0,010$ & 0,776 & $-0,004$ & 0,959 \\
\hline & $t$-stat & $-13,288$ & & $-18,845$ & & $-8,741$ & & $-2,166$ & & $-2,738$ & \\
\hline
\end{tabular}

\begin{tabular}{|c|c|c|c|c|c|c|c|c|c|c|c|}
\hline \multirow{2}{*}{\multicolumn{2}{|c|}{$\begin{array}{l}\text { Panel C : Carhart } \\
\text { model }\end{array}$}} & \multirow{2}{*}{$\begin{array}{c}\text { Full sample } \\
\text { Alpha }\end{array}$} & \multirow[b]{2}{*}{ Adj $R^{2}$} & \multicolumn{2}{|c|}{ P1 } & \multicolumn{2}{|c|}{ P2 } & \multicolumn{2}{|c|}{ P3 } & \multicolumn{2}{|c|}{ P4 } \\
\hline & & & & Alpha & Adj $R^{2}$ & Alpha & Adj $R^{2}$ & Alpha & Adj $R^{2}$ & Alpha & Adj $R^{2}$ \\
\hline \multirow[t]{2}{*}{ PTF All } & Coef. & $-0,021$ & 0,899 & $-0,028$ & 0,950 & $-0,044$ & 0,929 & $-0,009$ & 0,899 & $-0,005$ & 0,955 \\
\hline & $t$-stat & $-15,049$ & & $-21,674$ & & $-9,125$ & & $-3,303$ & & $-2,886$ & \\
\hline \multirow[t]{2}{*}{ PTF1 } & Coef. & $-0,022$ & 0,884 & $-0,028$ & 0,916 & $-0,046$ & 0,941 & $-0,011$ & 0,910 & $-0,006$ & 0,940 \\
\hline & $t$-stat & $-14,261$ & & $-16,973$ & & $-10,476$ & & $-3,878$ & & $-3,371$ & \\
\hline \multirow[t]{2}{*}{ PTF2 } & Coef. & $-0,020$ & 0,902 & $-0,027$ & 0,953 & $-0,042$ & 0,920 & $-0,008$ & 0,903 & $-0,004$ & 0,961 \\
\hline & $t$-stat & $-14,628$ & & $-21,526$ & & $-8,187$ & & $-2,964$ & & $-2,850$ & \\
\hline \multirow[t]{2}{*}{ PTF3 } & Coef. & $-0,021$ & 0,880 & $-0,028$ & 0,929 & $-0,040$ & 0,945 & $-0,010$ & 0,786 & $-0,004$ & 0,961 \\
\hline & $t$-stat & $-13,504$ & & $-17,821$ & & $-9,112$ & & $-2,145$ & & $-2,361$ & \\
\hline \multirow[t]{2}{*}{ PTF4 } & Coef. & $-0,022$ & 0,870 & $-0,029$ & 0,934 & $-0,041$ & 0,942 & $-0,010$ & 0,770 & $-0,004$ & 0,957 \\
\hline & $t$-stat & $-13,565$ & & $-18,993$ & & $-8,896$ & & $-2,098$ & & $-2,667$ & \\
\hline
\end{tabular}

\section{The potential SOURCES of economies of scale: Tests using MultileVel MODELS}

As we indicate in section 2, economies of scale can mainly be observed at fund family level. Indeed, fund family structure and governance appears to be the level on which benefits in terms of transaction and hierarchy costs can be reduced. At family level, gains in terms of sharing common skills, hard and soft information can be substantial. However, all models and previous 
tests are based on strong hypotheses that funds use same technologies and competition take place between funds. By definition, OLS regressions suppose independence of observations and omit that often funds are neither independent nor isolated. They belong to fund families which provide resources at their disposal. Multilevel models permit to take into account this nested nature of fund industry by separating from total fund variance, the common variance shared by funds belonging to same families (Goldstein (1986), Snijder and Bosker (1999)). By definition, this approach allows modeling heterogeneity of microeconomic units when these units belong to groups that are themselves heterogeneous and in competition. Thus, multilevel models appears to be more relevant to strength our tests on the existences of UCITS IV and economies of scale effects.

\section{METHODOLOGY}

Multilevel models are regression methods that combine fixed and random effects and explicitly take into account the hierarchical structure of observations. The principle is to decompose the total variance according to each level of interest. In our investigation, we consider three main levels of variance: (1) Intra-variance that explains the growth of fund size, (2) inter - fund variance that models the performance differences between funds and (3) inter - fund family variance, which explains the heterogeneity between fund families. The challenge is to handle in one block the decomposition of the dynamic relationship between the riskadjusted performance of funds and size. Specifically we test the following relationship:

$$
\begin{aligned}
\alpha_{i, j, t}=\beta_{0, j}+ & \beta_{1} \operatorname{LogTN} A_{i, j, t-1}+\beta_{2}\left(\operatorname{LogTN} A_{i, j, t-1}\right)^{2}+\sum_{K=3}^{K=4} \beta_{k} \text { Period } \\
& +\sum_{L=5}^{L=6} \beta_{L}{\text { Period } * \operatorname{LogTN} A_{i, j, t-1}+\sum_{M=7}^{M=8} \beta_{L} \text { Period } *\left(\operatorname{LogTN} A_{i, j, t-1}\right)^{2}}^{N=12} \beta_{N} \operatorname{Ctrl}_{i, j, t}+\epsilon_{i, j, t}
\end{aligned}
$$

This relation (equation 10) explains the risk adjusted performance $\alpha_{i, j, t}$ of fund $i$ belonging to a fund family $j$ measured for month $t$ as a quadratic relation with the size $\operatorname{LogTN} A_{i, j, t-1}$ et $\operatorname{LogTN} A_{i, j, t-1}{ }^{2}$ to which interaction effects with different periods and fund characteristic instruments are added. We introduce in this relation the random effects that allows to take into account for unobserved heterogeneity which indicates the membership of fund to a family. This specification tests whether a fund belonging to a family explains the 
differences in performance vis-à-vis funds belonging from other families. Specifically, we introduce random effects on the constant term (intercept) in the model. We vary this constant term depending on fund families assuming that it follows a normal distribution as following2:

$$
\beta_{0, j} \sim N\left(\delta_{00}, \sigma_{0}^{2}\right)
$$

Where $\sigma_{0}^{2}$ represent the estimated inter-group variance that has to be explained by family fund characteristic variables:

$$
\beta_{0, j}=\delta_{00}+\sum_{F=13}^{F=16} \delta_{0 F} *(\text { Family })_{j, t}+u_{0}
$$

Moreover, since we do not use conventional Fama-McBeth (1973) two steps methods we treat problems related to the existence autocorrelation of residuals by an autoregressive up to order 1 process:

$$
\begin{gathered}
\epsilon_{i, j, t}=\rho \epsilon_{i, j, t-1}+v_{i, j, t} \quad \text { où }|\rho|<1 \text { follow an AR(1) process } \\
v_{i, j, t} \sim N\left(0, \sigma_{v}^{2}\right) \\
\sigma_{\epsilon}^{2}=\frac{\sigma_{v}^{2}}{1-\rho^{2}}
\end{gathered}
$$

Substituting these equations in the overall econometric model, we get a following multilevel model with a random constant term (family level) and individual errors (fund level) autocorrelated up to order 1(AR1):

$$
\begin{aligned}
\alpha_{i, j, t}=\delta_{00}+\beta_{1} \operatorname{LogTN}_{i, j, t-1}+\beta_{2}\left(\operatorname{LogTNA}_{i, j, t-1}\right)^{2}+\sum_{K=3}^{K=4} \beta_{k} \text { Period }+\sum_{L=5}^{L=6} \beta_{L} \text { Period } * \text { LogTNA } A_{i, j, t-1} \\
+\sum_{M=7}^{M=8} \beta_{L} \text { Period } *\left(\operatorname{LogTNA}_{i, j, t-1}\right)^{2}+\sum_{N=9}^{N=12} \beta_{N} \operatorname{Ctrl}_{i, j, t}+\sum_{F=13}^{F=16} \delta_{0 F} *\left(\text { Family }_{j, t}\right)+u_{0} \\
+\rho \epsilon_{i, j, t-1}+v_{i, j, t}
\end{aligned}
$$

This model is composed by two main parts. The fixed part of the model can be explained as a classical cross-sectional OLS. The random part of the model $\left(u_{0}+\rho \epsilon_{i, j, t-1}+v_{i, j, t}\right)$ estimates the inter-family variance $u_{0}$, the intra-fund variance $\rho \epsilon_{i, j, t-1}$ and the residual $v_{i, j, t}$ that is

\footnotetext{
${ }^{2}$ In our study, we performed models with various random effects depending on the constant term and also depending to the size (LogTNA and $\log \mathrm{TNA}^{2}$ ). The aim is to examine if fund families explain the fund members size and performance relationship: $\left(\begin{array}{c}\beta_{0, j} \\ \beta_{1, j} \\ \beta_{2, j}\end{array}\right) \sim N\left(\begin{array}{cc}\delta_{00} & \sigma_{0}^{2} \\ \delta_{10} & \sigma_{1}^{2} \\ \delta_{20} & \sigma_{2}^{2}\end{array}\right)$. Results are inconclusive and not reported here.
} 
supposed to be i.i.d. and homoscedastic. This specification allows to perform extensive tests on the existence and the shape of the relationship between size and performance not only at fund level but also at family level. Three sets of tests can be performed.

A first set related to the existence of "fund family effect":

- T1: $\sigma_{0} \neq 0$. It tests if the variance of the random constant term in the model is significantly different from zero (Wald Z-test). The objective is to examine if fund family has a direct effect on fund member performance.

A second set of tests related on the shape of the relationship of size and performance:

- T2: $\beta_{1}=0 ; \beta_{2}=0$. There is no relation between size and performance

- T3: $\beta_{1}<0 ; \beta_{2}=0$. There is a linear and negative relation between size and performance consisting with theoretical background.

- T4: It tests if there is a quadratic relation between size and performance:

○ Concave: $\beta_{1}>0 ; \beta_{2}<0$

○ Convexe: $\beta_{1}<0 ; \beta_{2}>0$

A third set of tests related to the existence of UCITS IV effects and the presence of economies of scale:

- T5: $\beta_{3}, \beta_{4}, \beta_{5}, \beta_{6}, \beta_{7}, \beta_{8} \neq 0$.

In our investigation we test three different specification models to avoid the presence of multi-collinearity between family specific variables. Appendix 2 displays correlation matrix between all variables used in our tests. We perform all tests for the three different periods as a single block ${ }^{3}$.

- Model 1: a standard model that includes family level variable such as the size of the family (logFamSize). The expected sign of the estimated coefficient is positive, showing thereby that family is supposed to have important resources that they effectively manage so as to benefit from economies of scale.

- Model 2: a model based on the number of funds offered by the family irrespective of the overall size. This model should account for the effects of sharing information between managers within fund families with more or less diversified profile. Three family-level variables are integrated over here: the concentration index depending on the number of

${ }^{3}$ The correlation matrix between different variables and instruments is presented in Appendix 3. 
Lipper class (HHI_N_LC), Large fund family (Large_20), the concentration index depending on the number of domicile (HHI_D)

- Model 3: a model based on fund family financial resources, calculated from the TNA with a focus on equity funds. Three family characteristic variables are used in this model: the concentration index depending on domiciliation of equity funds (HHI_D_EQ), the concentration index depending on the weight of the fund Lipper class compared to all family Lipper classes (HHI_TNA_LC) and Large Equity Families (EQ_Large 20).

\section{RESULTS}

For each of the three specifications, we perform regressions using monthly rolling alphas estimated with the three different benchmark factors models, respectively the 1-factor CAPM, the 3-factors Fama-French and the 4-factors Carhart. The alpha coefficients are monthly estimated over 36-month rolling periods. The graphs presented in Appendix 3 shows the time series of the average alphas. These figures allow us to visually confirm the consistency between defined sub-periods and the time-varying changes in the dynamic of European fund performances (see Appendix 3).

For our regressions with multilevel models, we use restricted maximum likelihood estimator (REML). In line of studies using financial data series including crisis periods, we exclude the period P2 from all our tests. Indeed, this period poses convergence problems of estimators due to the high volatility and high correlations between the data series. Thus, we perform panel regressions directly on our three defined periods P1, P3 and P4. We use the period P4 corresponding to UCITS IV Directive adoption as reference. To limit the impact of outliers on our estimations, we exclude $2.5 \%$ to $2.5 \%$ at the right and left of the fund's size distribution

Table 6 hereafter reports the overall results for our estimates. These results call for four main sets of comments.

\section{On the existence of decreasing returns of scale.}

Referring to Berk and Green (2004) and Chen et al. (2004) seminal works, the size and performance relationship is negative. More investment funds are growing, less performance will be higher (Pollet \& Wilson (2008), Stein (2002), Edelen et al. (2007)). So there are diseconomies of scale related either to the existence of liquidity constraints and increased hierarchy costs. Empirically, the answers to the shape of size and performance relationship are mixed. Various studies have concluded that there are significant relation with two types of 
shape: a negative and linear relationship and a quadratic and concave relationship. ${ }^{4}$ These two forms of relationship are consistent with theoretical assumptions. Moreover, the quadratic and concave relationship allows to identify the optimal size from which performance decreases.

Globally, all our tests validate the hypothesis of a quadratic relationship between the size and performance. ${ }^{5}$ Constant terms (intercept) $\beta_{0}$ are significant and vary from -2.8 percent to 4.65 percent, except for 4-factors Carhart estimation on the period P1. $\beta_{1}$ and $\beta_{2}$ coefficients related to the size and performance dynamics and associated to LogTNA and (LogTNA) ${ }^{2}$ are significant, except for $\beta_{1}$ for 1 -factor CAPM estimation on the period P1. Signs of $\beta_{1}$ (negative) and $\beta_{2}$ (positive) related to the reference period (P4) indicate a quadratic and convex relationship between size and performance. For P1 and P3, results are in line with previous studies. Respectively the corresponding coefficients $\beta_{5}$ et $\beta_{6}$ associated to LogTNA are positive and $\beta_{7}$ et $\beta_{8}$ associated to $\operatorname{LogTNA}^{2}$ are negative. This indicates a quadratic and concave relation. This contrasting result seems to show that the after UCITS IV period appears to represent a new regime on the relation between size and performance for European funds. They seem to benefit from gains related to size and not face to diseconomies of scale..

\footnotetext{
${ }^{4}$ See Bodson (2011) for an extensive review.

${ }^{5}$ Some explanation for the reading and commentary of the results displayed in Table 6. Main coefficients correspond to those of reference value (period P4), denoted REF. To obtain coefficients related to the other period, one must add to REF coefficient terms gave by interaction effects. For example, for the constant term (column 1), REF indicated -0.034759 , so the constant term for P1 is $-0.032722(=-0.034759+0.002038)$. See Appendix 4 for an aggregate table of coefficients associated with the relationship size - Performance;
} 


\begin{tabular}{|c|c|c|c|c|c|c|c|c|c|c|c|c|c|c|c|c|}
\hline & \multicolumn{4}{|c|}{ Model 1} & \multicolumn{6}{|c|}{ Model 2} & \multicolumn{6}{|c|}{ Model 3} \\
\hline & CAPM & Fama - French & \multicolumn{2}{|l|}{ Carhart } & \multicolumn{2}{|l|}{ CAPM } & \multicolumn{2}{|c|}{ Fama - French } & \multicolumn{2}{|l|}{ Carhart } & \multicolumn{2}{|l|}{ CAPM } & \multicolumn{2}{|c|}{ Fama - French } & \multicolumn{2}{|c|}{ Carhart } \\
\hline \multicolumn{17}{|c|}{ RANDOM EFFECTS } \\
\hline Constant term variance $\left(\sigma_{0}^{2}\right)$ & $0,000005 \quad * * *$ & $0,000007 \quad * * *$ & 0,000006 & $* * *$ & 0,000006 & $* * *$ & 0,000007 & $* * *$ & 0,000004 & $* * *$ & 0,000007 & $* * *$ & 0,000008 & $* * *$ & 0,000005 & $* * *$ \\
\hline $\operatorname{AR}(\mathbf{1})$ & $0,988800 \quad * * *$ & $0,990200 \quad * * *$ & 0,988500 & $* * *$ & 0,988500 & $* * *$ & 0,990200 & $* * *$ & 0,988900 & $* * *$ & 0,988300 & $* * *$ & 0,990100 & $* * *$ & 0,988800 & $* * *$ \\
\hline Residuals $(\varepsilon)$ & $0,000121 \quad * * *$ & $0,000150 \quad * * *$ & 0,000153 & $* * *$ & 0,000153 & $* * *$ & 0,000149 & $* * *$ & 0,000122 & $* * *$ & 0,000151 & $* * *$ & 0,000148 & $* * *$ & 0,000120 & $* * *$ \\
\hline
\end{tabular}

$* p<0.1 * * p<0.05^{* * *} p<0.01$ 


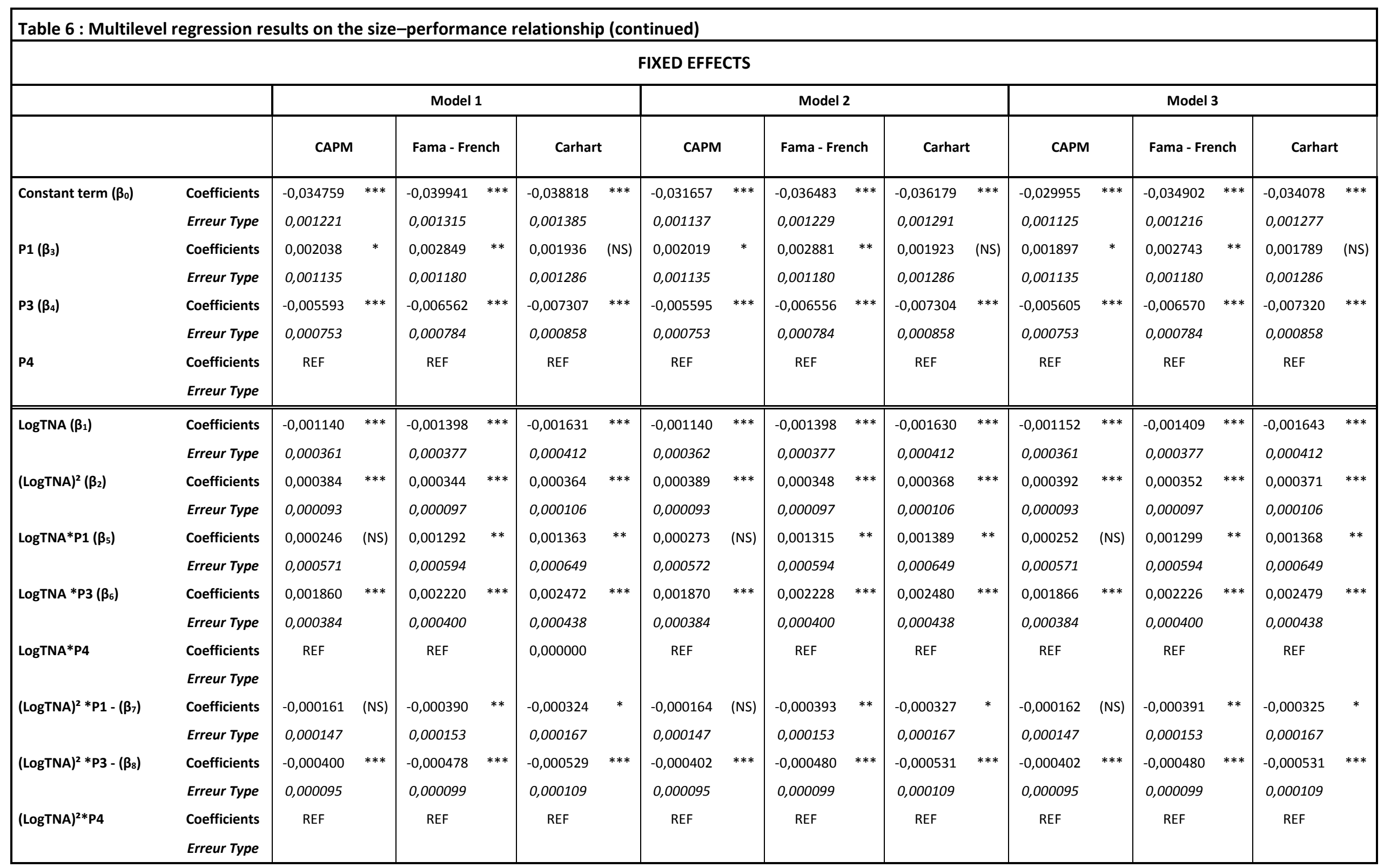

$* p<0.1 * * p<0.05 * * * p<0.01$ 


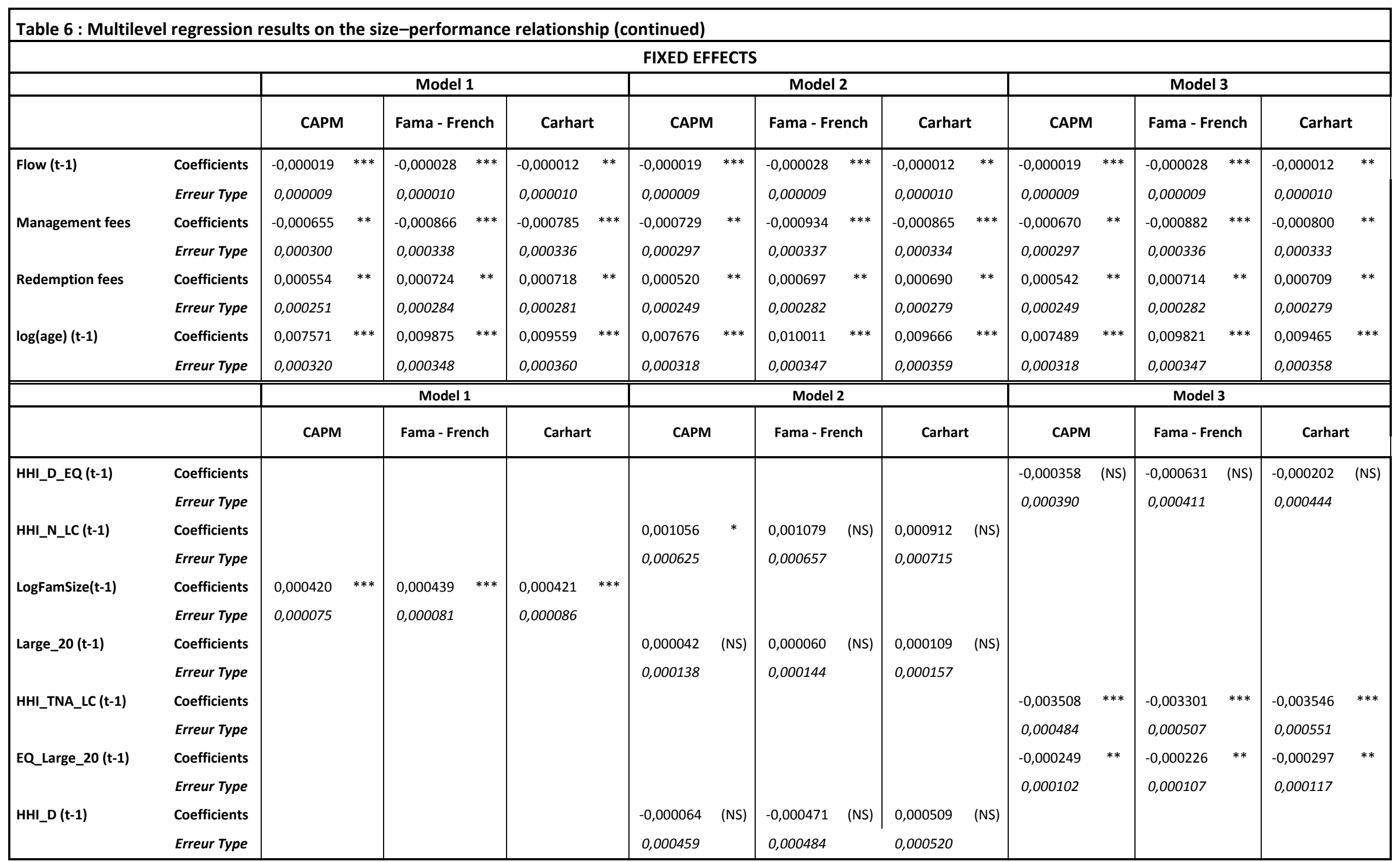

${ }^{*} p<0.1 * * p<0.05^{* * *} p<0.01$ 


\section{On the existence of UCITS IV effects}

The existence of UCITS IV effects can be observed through $\beta_{3}, \beta_{4}, \beta_{5}, \beta_{6}, \beta_{7}, \beta_{8}$ coefficients. As indicated previously, all coefficients are significant, except for $\beta_{3}$ and $\beta_{5}$ estimated on the period P1 with respectively the 4-factors Carhart and 1-factor CAPM models. Estimations made with the 3-factors Fama-French model are spotless, so we will refer to it for all our comments.

As with our previous portfolio approach tests, the hypothesis of the existence of UCITS IV effects is no rejected by the data with multilevel estimation. If one takes all coefficients obtained with 3-factors Fama-French and the third specification (model 3), one can form the equation relying size and performance for the three considered periods.

- For $P 1, \alpha_{i}=-0.0032-0.00011 \times \operatorname{LogTN} A_{i}-0.00004 \times\left(\operatorname{LogTN} A_{i}\right)^{2}$

- For P3, $\alpha_{i}=-0.0041+0.00082 \times \operatorname{LogTN} A_{i}-0.00013 \times\left(\operatorname{LogTN} A_{i}\right)^{2}$

- $F o r P 4, \alpha_{i}=-0.0035-0.00014 \times \operatorname{LogTN} A_{i}+0.00035 \times\left(\operatorname{LogTN} A_{i}\right)^{2}$

From these equations, figure 3 below draws graphs simulating size and performance relation. To have a clear view of the impact of UCITS IV, we let the size to vary from 5 million $€$ to 5 billion €.

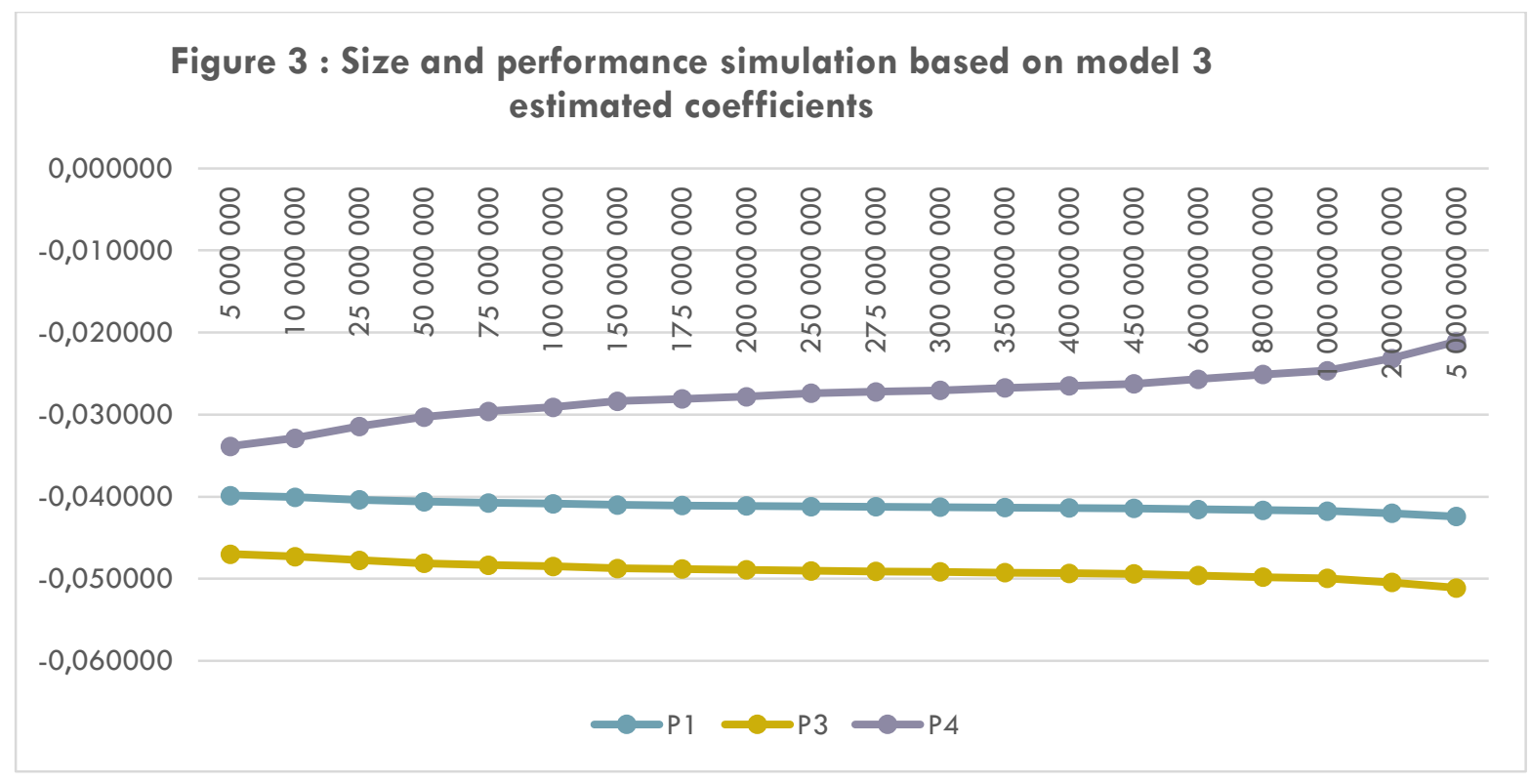

This simulation highlights two major observations. On the one hand, the performance associated with the period P4 is substantially greater than the two other periods. On the other hand, the performance dynamic is growing with the size for the period P4 while it decreases for 
the two other periods. ${ }^{6}$ These results seem to confirm the issues of Pastor and Stambaugh $(2011,2014)$ theoretical model which states that economies of scale vary according to market conditions. P1 and P4 periods both occur following a period of financial crises (dot.com for P1 and subprime for P4), while the period P3 corresponds to a market upward trend. The Pastor and Stambaugh model shows that the extent of diseconomies of scale depends on the overall size of the active management industry. The larger is this industry, the greater is the competition between funds. This reduces investment opportunities and, ultimately, degrades performance. As a reaction, investors transfer their capital to fund passive management which consequently decreases the size of the active management industry and reduced the magnitude of diseconomies of scale. Thus, the after subprime crisis, here the period P3, corresponds to a situation where the active management industry is at its lowest level. Thus, competition between active managers is very low justifying the concave relationship observed during this period. Conversely, P1 and P4 periods correspond to market upward periods. So consisting with literature, the overall size of active management industry increased during these periods which increased in turn the competition and the extent of diseconomies of scale up to the point where size and performance relationship becomes negative. The difference between P1 and P4 corresponds mainly to the extent of diseconomies of scale. Whereas P1 is almost linear and negative, the convex form for P4 clearly indicates that there is a premium to the largest funds. This is precisely the objective pursued by the UCITS IV Directive.

\section{On the fund family effects and the potential sources of economies of scale}

In theory, economies of scale may exist at fund family level. Many studies have shown this positive relationship between the fund family size and the performance of individual fund members. On the one hand, fund members of large families can take advantages of greater resources in research and expertise, sharing of transaction and credit costs (Chen et al (2004), Ferreira (2013)). On the other hand, large fund families can organize themselves to smooth the performance of fund members by transferring performance from high fees fund to low fees fund. We can add to this the fact that large families are committed to create fund stars that generate capital inflows for itself and for other fund members of the family (Nanda et al. (2004), Massa (2006)).

In our study, two parts in Table 6 allow to read the existence or not the fund family effects and the potential sources of economies of scale. Tests related to the existence of "fund family

\footnotetext{
${ }^{6}$ We performed the same simulation for models 1 and 2 and all benchmark models. The results, not reported here, are identical.
} 
effect" is reported on the top of table 6 (random effects). We observed that the variance of the constant term is significantly different from zero, $\left(\sigma_{0} \neq 0\right)$ at $1 \%$ level. It indicates that fund families explain and have a direct effect of the performance variation of fund members. More importantly, tests on variables related to fund family characteristics and associated to our three models give us a clear indication of the extent of the fund family effects.

Our standard model (model 1) that includes lagged fund family size (logFamSize) as control variable is conclusive and validate theoretical assumptions. All estimated coefficients with the three benchmark models are positive and highly significant. These results confirm Chen et al. (2004) and Ferreira (2013) issues which stated that family size has positive effects on fund members' performance. Thus, families that manage their resources efficiently can benefit their members by generating substantial economies of scale.

For the model 2 based on the number of funds offered by the family irrespective to the overall size, none of the three considered control variables displays significant coefficients, except for CAPM model though at 10\% level. The first variable (concentration index depending on the number of Lipper class, HHI_N_LC) displays a positive and significant coefficient only with the CAPM estimation. This indicates that family with a high concentration in terms of asset classes has positive effects on fund members' performance. This result is consistent with previous theoretical assumptions which state that high concentration implies effective resources control and a better expertise of these classes. This logically allows economies of scale. However, this result has to be nuanced since it is limited to CAPM model estimation. This suggests further investigations to better understand all impacts taking into account the heterogeneity of styles and strategies. The second control variable (Large fund family, Large_20) is non-significant. It indicates that belonging to a very large fund family does not necessarily benefit from additional performance, especially when the family is highly diversified. For the third control variable (concentration index depending on the number of domicile (HHI_D), we expected a negative and significant effect to the extent that it is a major component of the UCITS IV Directive. Indeed, by reducing the number of domicile, the European passport would reduce the costs for the internationalization of fund families. This internationalization would allow families, especially the largest, access to investment opportunities by reducing the costs, and then should positively impact the performance. However, our tests shows that all estimated coefficients are not significant. These results simply indicate that there is no direct relation between fund performance and number of fund domicile. 
The model 3 based on fund family resources and focused on equity provides the most conclusive results. Two of the three considered fund family characteristic variables show significant coefficients. The first variable (concentration index depending on domiciliation of equity funds, HHI_D_EQ) display non-significant estimated coefficients. As for the model 2, we observe no direct relation between fund performance and number of equity fund domicile. Fund domiciliation does not appear to be a main determinant for benefit from either economies or even diseconomies of scale. This probably explains why the average level of concentration by domicile (see above Table 3) stayed constant before and after UCITS IV Directive despite the generalization of the notification procedure through the European passport.

The second variable (concentration index depending on the weight of the fund Lipper class compared to all family Lipper classes, HHI_TNA_LC) displays negative and significant coefficients for all benchmark model estimations. This indicates to the fund family that a high concentration in terms of allocation of financial resources have negative effects on the performance of its members. In theory, belonging to a family may induce to positive spillover effects once the organization promotes the sharing of information and resources. It can have negative spillover effects if the hierarchy costs increase and the organization spur more competition between managers and cause cannibalization between funds. With regard to our findings, the result of a negative effect can be explained easily. As we observed in our descriptive statistics (see Table 3), the European fund families have specific characteristics. On the one hand, they have a very high number of members, more than 50 on average with standard deviations up to 100 . On the other hand, they display low concentration indexes depending on Lipper class, around 19 percent if one refers to the number of Lipper classes; around 30 percent if one refers to the size of Lipper classes. Thus, European fund families are highly diversified. This diversification can probably be beneficial as it helps to be on the lookout for many investment opportunities. Nevertheless, it requires in return a more appropriate organization to effectively share information and resources, and so to benefit from positive common skills effects. This does not seem to be the case of European funds in our study. Herein, the negative sign simply indicates the existence of significant hierarchy costs which burden the performance. The third variable (Large Equity Families, EQ_Large 20) displays negative and significant coefficients for all estimations. We can do the same comments as for the earlier variable. Indeed, we are in the presence of diseconomies of scale phenomenon. Overall, the strong specialization of the family in Equity fund induces negative spillover effects. 


\section{On the standard control variables}

The estimated coefficients of our four control variables call for short comments. All coefficients are significant for all estimations. Estimated coefficients associated to the lagged flows are negative consisting with main empirical studies. By definition, flows mechanically increase fund size which in turn increases the liquidity and hierarchy costs. More interestingly, management fees have a negative effect. More the fund is expensive, lower is its performance, and vice versa. This result is consistent with a recent literature based on the Gil-Bazo agency model and Ruiz (2009). Similarly, the redemption fees have positive effects on performance. This illustrates that funds with high back load fees are also the most stable and this reduces agency costs between investors and fund managers (Chordia, 1996). Finally, the coefficient associated with age is positive which is paradoxical. We can argue that this effect is related to the outperformance of the largest funds which are not by its nature the youngest.

\section{CONCLUSION}

Since its launch in 1985, UCITS Directive gradually change the universe of fund investment in Europe. The main purpose is the development of an integrated market and strengthening the competitiveness of European funds through improved coordination between regulators and reinforced investors protection. With the adoption of UCITS IV Directive in 2011, a big step was taken. By enabling more cost effective notification procedures and by introducing framework for merging funds, UCITS IV Directive tend to encourage the development of a much bigger average fund size, conducive to a large, fluid and integrated European market with harmonized regulation.

In this paper we study the impact of the UCITS IV Directive (Undertakings for the Collective Investment in Transferable Securities, adopted in 2011) on the dynamics of European mutual funds. Our central hypothesis is based on the fact that UCITS IV Directive should benefit both managers and investors by facilitating the emergence of economies of scale. From this central point we draw two testable hypotheses regarding to the existence of UCITS IV effects and to the emergence of economies of scale. To do this, we follow the equilibrium of mutual fund industry approach developed by Berk and Green (2004) and Chen et al. (2004) which introduce the concept of diseconomy of scale in active management portfolio. This approach provides methodologies to test the relationship between size and performance and also to identify the potential sources of economies of scale. In a sample of 1435 European Equity funds from December 2001 to December 2013, we successively perform two main empirical investigations. From the first set of tests based on portfolio approach, the hypothesis of the existence of UCITS 
IV effects is not rejected by data. As observed with descriptive statistics, performance after UCITS IV are significantly superior to those of previous periods. Nonetheless, the results related to the existence of economies of scale are mixed. Even one noticed a reversion in performance order for small and large fund portfolios, the difference between them are too small for more relevant comments. Our second set of tests with trans-logarithmic model and multilevel panel regression methods provides more interesting results.

First regarding the existence of UCITS effects and economies of scale. All our tests validate the hypothesis of a quadratic relationship between size and performance. European equity funds display a quadratic and concave form before UCITS IV and a quadratic and convex form after. These contrasting results seem to show that the after UCITS IV period represent a new regime on the relation between size and performance for European funds. The performance is growing with the size while it decreases for the two previous periods. They seem to benefit from gains related to size and not face to diseconomies of scale. The convex form clearly indicates that there is a premium to the largest funds. This is precisely the objective pursued by the UCITS IV Directive.

Second, the potential sources and the extent of economies of scale have to be nuanced by results from family specific characteristic variables under consideration. According to Chen et al. (2004) and Ferreira (2013), we find that family size has positive and highly significant effects on European fund performance. Surprisingly, none of variables related to the number of funds offered by family, the dummy variable indicating large family (up to 20 members) and especially the number of domicile are non-significant. We expected negative effects. However we simply observe an absence of significant relation between these variables and fund performance. This suggests some extensions of our tests and specification models with other family specific characteristics and additional variables. The last two variables related to fund family financial resources give some relevant insights. As expected large families in terms of equity fund members display negative and significant spillover effects on fund performance. In the same way, family that is broadly diversified in terms of capital allocation among Lipper classes does not benefit positive common skill effects to its members. The negative and highly significant coefficient signs simply indicate the existence of hierarchy costs and somehow the presence of diseconomies of scale. Herein, as observed in descriptive statistics, family specific characteristics of European fund, with high number of members and a broad diversification burden the performance. 


\section{RefERENCES}

Banegas A. et al. (2013): "The cross section of conditional mutual fund performance in European stock markets", Journal of Financial Economics, 108(2013) 699-726.

Barber, B. M., Odean, T., and Zheng, L. (2005). Out of Sight, Out of Mind: The Effects of Expenses on Mutual Fund Flows*. Journal of Business, 78(6), 2095-2120.

Bergstresser, D., Chalmers, J. M., and Tufano, P. (2009). Assessing the costs and benefits of brokers in the mutual fund industry. Review of Financial Studies, 22(10), 4129-4156.

Berk J. and R. Green (2004): "Mutual Fund Flows and Performance in Rational Markets", Journal of Political Economy, 112, 1269-1295.

Brown, D. P., and Wu, Y. (2015). Mutual Fund Flows and Cross-Fund Learning Within Families. Forthcoming, Journal of Finance.

Capon, N., Fitzsimons, G. J., and Prince, R. A. (1996). An individual level analysis of the mutual fund investment decision. Journal of financial services research, 10(1), 59-82.

Carhart (1997): « On persistence in mutual fund performance », Journal of Finance, 52, 57-87

Chen et al. (2004): «Does fund size erode performance », American Economic Review, 94, 12761302

Chen, J., Hong, H., Jiang, W., and Kubik, J. D. (2013). Outsourcing mutual fund management: firm boundaries, incentives, and performance. Journal of Finance, 68(2), 523-558.

Chordia T (1996): "The structure of mutual fund charges", Journal of Financial Economics 41, 1, May, 3-39.

Dangl, T., Wu, Y., and Zechner, J. (2008). Market discipline and internal governance in the mutual fund industry. Review of Financial Studies, 21(5), 2307-2343.

Fama \& French (1992): “The cross section of expected stock returns", Journal of Finance, 47, 427-465

Ferreira M. et al. (2013): "The Determinants of Mutual Fund Performance: A Cross-Country Study", Review of Finance (2013) 17: pp. 483-525.

Gaspar, J. M., Massa, M., and Matos, P. (2006). Favoritism in mutual fund families? Evidence on strategic cross-fund subsidization. Journal of Finance, 61(1), 73-104. 
Gil-Bazo J and Ruiz - Verdu P. (2009): "The Relation between Price and Performance in the Mutual Fund Industry", Journal of Finance, 64, 5, 2153-2183

Goetzmann, W. N., and Peles, N. (1997). Cognitive dissonance and mutual fund investors. Journal of financial Research, 20(2), 145-158.

Goldstein, H. (1986). Multilevel mixed linear model analysis using iterative generalized least squares. Biometrika, 73, 43-56.

Gruber, M. J. (1996). Another puzzle: The growth in actively managed mutual funds. Journal of Finance, 51(3), 783-810.

Guercio, D. D., and Reuter, J. (2014). Mutual fund performance and the incentive to generate alpha. Journal of Finance, 69(4), 1673-1704.

Guercio, D. D., and Tkac, P. A. (2008). Star power: The effect of morningstar ratings on mutual fund flows. Journal of Financial and Quantitative Analysis,43(04), 907-936.

Hortaçsu, A., and Syverson, C. (2004). Product Differentiation, Search Costs, and Competition in the Mutual Fund Industry: A Case Study of SandP 500 Index Funds*. The Quarterly journal of economics, 119(2), 403-456.

Jain, P. C., and Wu, J. S. (2000). Truth in mutual fund advertising: Evidence on future performance and fund flows. Journal of Finance, 55(2), 937-958.

Kacperczyk, M., Sialm, C., and Zheng, L. (2005). On the industry concentration of actively managed equity mutual funds. Journal of Finance, 60(4), 1983-2011.

Kacperczyk, M., Sialm, C., and Zheng, L. (2008). Unobserved actions of mutual funds. Review of Financial Studies, 21(6), 2379-2416.

Kempf, A., and Ruenzi, S. (2008). Family matters: rankings within fund families and fund inflows. Journal of Business Finance and Accounting, 35(1-2), 177-199.

Khorana A., Servaes H. and P. Tufano (2005): "Explaining the size of mutual fund industry around the world", Journal of Financial Economics, 78, 145-185

Khorana, A., and Servaes, H. (1999). The determinants of mutual fund starts. Review of Financial Studies, 12(5), 1043-1074.

Khorana, A., and Servaes, H. (2012). What drives market share in the mutual fund industry? Review of Finance, 16(1), 81-113. 
Klapper L., Sulla V. and D. Vittas (2004): “The development of mutual funds around the world”, Emerging Markets Review 5 (2004) 1-38.

Kosowski, R., Timmermann, A., Wermers, R., and White, H. (2006). Can mutual fund "stars" really pick stocks? New evidence from a bootstrap analysis. Journal of finance, 61(6), 25512595.

Massa, M. (1998). Why so many mutual funds? Mutual fund families, market segmentation and financial performance. Mutual Fund Families, Market Segmentation and Financial Performance, working paper

Massa, M. (2003). How do family strategies affect fund performance? When performancemaximization is not the only game in town. Journal of Financial Economics, 67(2), 249-304.

Massa, M., and Rehman, Z. (2008). Information flows within financial conglomerates: Evidence from the banks-mutual funds relation. Journal of Financial Economics, 89(2), 288-306.

Nanda, V., Wang, Z. J., and Zheng, L. (2004). Family values and the star phenomenon: Strategies of mutual fund families. Review of Financial Studies. 17, 667-698.

Nanda, V. K., Wang, Z. J., and Zheng, L. (2009). The ABCs of mutual funds: On the introduction of multiple share classes. Journal of Financial Intermediation, 18(3), 329-361.

Otten R. and D. Bams (2002): "European Mutual fund industry", European Financial Management, 8, 75-10.

Pástor, L., \& Stambaugh, R. F. (2012). On the Size of the Active Management Industry. Journal of Political Economy, 120(4), 740-781.

Pástor, L., Stambaugh, R. F., and Taylor, L. A. (2015). Scale and skill in active management. Journal of Financial Economics, 116(1), 23-45.

Ramos S. (2009): "The Size and Structure of the World Mutual Fund Industry", European Financial Management, Vol. 15, No. 1, 2009, 145-180

Sirri, E. R., and Tufano, P. (1998). Costly search and mutual fund flows. Journal of finance, 15891622.

Snijders, T., \& Bosker, R. (1999). Multilevel analysis: an introduction to basic and advanced multilevel modeling. London: Sage.

Stein, J. C. (1997). Internal Capital Markets and the Competition for Corporate Resources. Journal of Finance, 52(1), 111-133. 
Stein, J. C. (2002). Information Production and Capital Allocation: Decentralized versus Hierarchical Firms. Journal of Finance, 57(5).

Stoughton, N. M., Wu, Y., and Zechner, J. (2011). Intermediated investment management. Journal of Finance, 66(3), 947-980.

Vidal-García Javier (2013): “The persistence of European mutual fund performance”, Research in International Business and Finance 28 (2013) 45- 67.

Wilcox, R. T. (2003). Bargain Hunting or Star Gazing? Investors' Preferences for Stock Mutual Funds*. The Journal of Business, 76(4), 645-663. 


\section{APPENDIX}

- Appendix 1: Summary statistics of benchmark factors

- Appendix 2: Correlation matrix among all variables

- Appendix 3: Estimated marginal mean of alphas by quartile

- Appendix 4: Aggregate estimated coefficients for Size - Performance with multilevel regression 
Appendix 1

Summary statistics of benchmark factors

\begin{tabular}{|c|c|c|c|c|c|c|}
\hline \multirow[b]{2}{*}{ Factors } & \multirow{2}{*}{ Mean return* } & \multirow{2}{*}{ Std dev.* } & \multicolumn{4}{|c|}{ Cross-correlation } \\
\hline & & & $M k t-R F$ & $S M B$ & $H M L$ & MOM \\
\hline Market & 0,366 & 16,060 & 1,000 & & & \\
\hline SMB & 1,040 & 3,612 & 0,102 & 1,000 & & \\
\hline HML & 1,332 & 1,955 & $-0,245$ & 0,438 & 1,000 & \\
\hline MOM & 1,629 & 2,419 & $-0,253$ & 0,035 & $-0,073$ & 1,000 \\
\hline
\end{tabular}




\begin{tabular}{|c|c|c|c|c|c|c|c|c|c|c|c|c|c|c|c|c|c|c|c|}
\hline \multicolumn{20}{|c|}{ Appendix 2 : Correlation matrix among all variables } \\
\hline Variables & $\begin{array}{l}4 \\
\overbrace{1} \\
\frac{\pi}{\frac{\pi}{0}} \\
\frac{0}{\pi}\end{array}$ & $\begin{array}{l}\tilde{m}_{1} \\
\frac{\pi}{\sigma} \\
\frac{\vec{c}}{\sigma}\end{array}$ & $\begin{array}{l}\text { 守 } \\
\text { 采 } \\
\frac{0}{0}\end{array}$ & $\underset{\substack{0 \\
0}}{\sum_{0}}$ & $\begin{array}{l}\frac{N}{8} \\
\frac{1}{20} \\
\stackrel{0}{U}\end{array}$ & 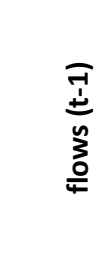 & 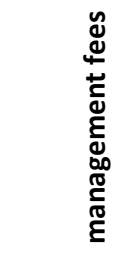 & 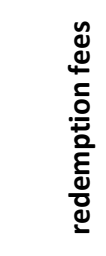 & 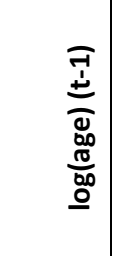 & $\begin{array}{l}E \\
\substack{\pi \\
\sum_{00}} \\
0\end{array}$ & 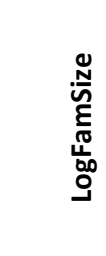 & 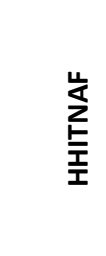 & 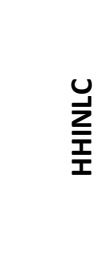 & 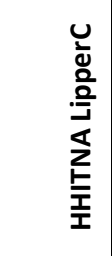 & 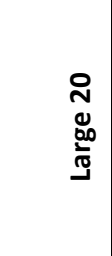 & $\begin{array}{l}\text { 㗊 } \\
\text { 至 }\end{array}$ & 呈 & 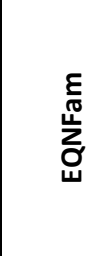 & 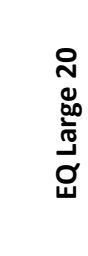 \\
\hline alpha_1f & 1,000 & & & & & & & & & & & & & & & & & & \\
\hline alpha_3f & 0,963 & 1,000 & & & & & & & & & & & & & & & & & \\
\hline alpha_4f & 0,952 & 0,989 & 1,000 & & & & & & & & & & & & & & & & \\
\hline LogTNA & 0,090 & 0,100 & 0,099 & 1,000 & & & & & & & & & & & & & & & \\
\hline$(\text { LogTNA })^{2}$ & 0,071 & 0,081 & 0,079 & 0,939 & 1,000 & & & & & & & & & & & & & & \\
\hline flows (t-1) & 0,003 & 0,002 & 0,002 & $-0,002$ & $-0,002$ & 1,000 & & & & & & & & & & & & & \\
\hline Management fees & $-0,024$ & $-0,027$ & $-0,024$ & $-0,001$ & $-0,016$ & $-0,005$ & 1,000 & & & & & & & & & & & & \\
\hline Redemption fees & $-0,001$ & 0,001 & 0,001 & $-0,054$ & $-0,059$ & $-0,001$ & $-0,043$ & 1,000 & & & & & & & & & & & \\
\hline $\log ($ age $)(t-1)$ & 0,151 & 0,142 & 0,140 & 0,210 & 0,214 & $-0,002$ & 0,061 & $-0,071$ & 1,000 & & & & & & & & & & \\
\hline LogNfam & $-0,046$ & $-0,035$ & $-0,030$ & 0,164 & 0,156 & $-0,004$ & $-0,004$ & $-0,008$ & 0,087 & 1,000 & & & & & & & & & \\
\hline LogFamSize & $-0,045$ & $-0,034$ & $-0,030$ & 0,163 & 0,156 & $-0,004$ & $-0,003$ & $-0,008$ & 0,088 & 1,000 & 1,000 & & & & & & & & \\
\hline HHITNAF & 0,020 & 0,011 & 0,009 & $-0,189$ & $-0,169$ & 0,002 & 0,028 & 0,028 & $-0,148$ & $-0,752$ & $-0,751$ & 1,000 & & & & & & & \\
\hline HHINLC & $-0,017$ & $-0,022$ & $-0,023$ & $-0,176$ & $-0,161$ & 0,006 & 0,017 & 0,070 & $-0,121$ & $-0,505$ & $-0,504$ & 0,685 & 1,000 & & & & & & \\
\hline HHITNA LipperC & $-0,030$ & $-0,039$ & $-0,039$ & $-0,219$ & $-0,201$ & 0,005 & 0,060 & 0,007 & $-0,145$ & $-0,525$ & $-0,523$ & 0,822 & 0,702 & 1,000 & & & & & \\
\hline Large 20 & 0,006 & 0,014 & 0,016 & 0,185 & 0,172 & $-0,005$ & $-0,017$ & $-0,011$ & 0,131 & 0,754 & 0,753 & $-0,687$ & $-0,510$ & $-0,533$ & 1,000 & & & & \\
\hline HHIDEQ & 0,006 & $-0,001$ & 0,000 & $-0,136$ & $-0,121$ & 0,002 & 0,041 & $-0,010$ & $-0,068$ & $-0,541$ & $-0,540$ & 0,387 & 0,317 & 0,473 & $-0,403$ & 1,000 & & & \\
\hline HHID & 0,009 & 0,004 & 0,005 & $-0,150$ & $-0,136$ & 0,002 & 0,048 & $-0,006$ & $-0,074$ & $-0,542$ & $-0,542$ & 0,402 & 0,342 & 0,496 & $-0,406$ & 0,934 & 1,000 & & \\
\hline EQNFam & $-0,102$ & $-0,096$ & $-0,090$ & 0,142 & 0,152 & $-0,002$ & $-0,015$ & $-0,018$ & 0,045 & 0,822 & 0,822 & $-0,465$ & $-0,280$ & $-0,308$ & 0,443 & $-0,456$ & $-0,484$ & 1,000 & \\
\hline EQ Large 20 & $-0,030$ & $-0,026$ & $-0,028$ & 0,227 & 0,229 & $-0,003$ & $-0,029$ & $-0,019$ & 0,095 & 0,767 & 0,767 & $-0,540$ & $-0,379$ & $-0,396$ & 0,620 & $-0,507$ & $-0,490$ & 0,651 & 1,000 \\
\hline
\end{tabular}




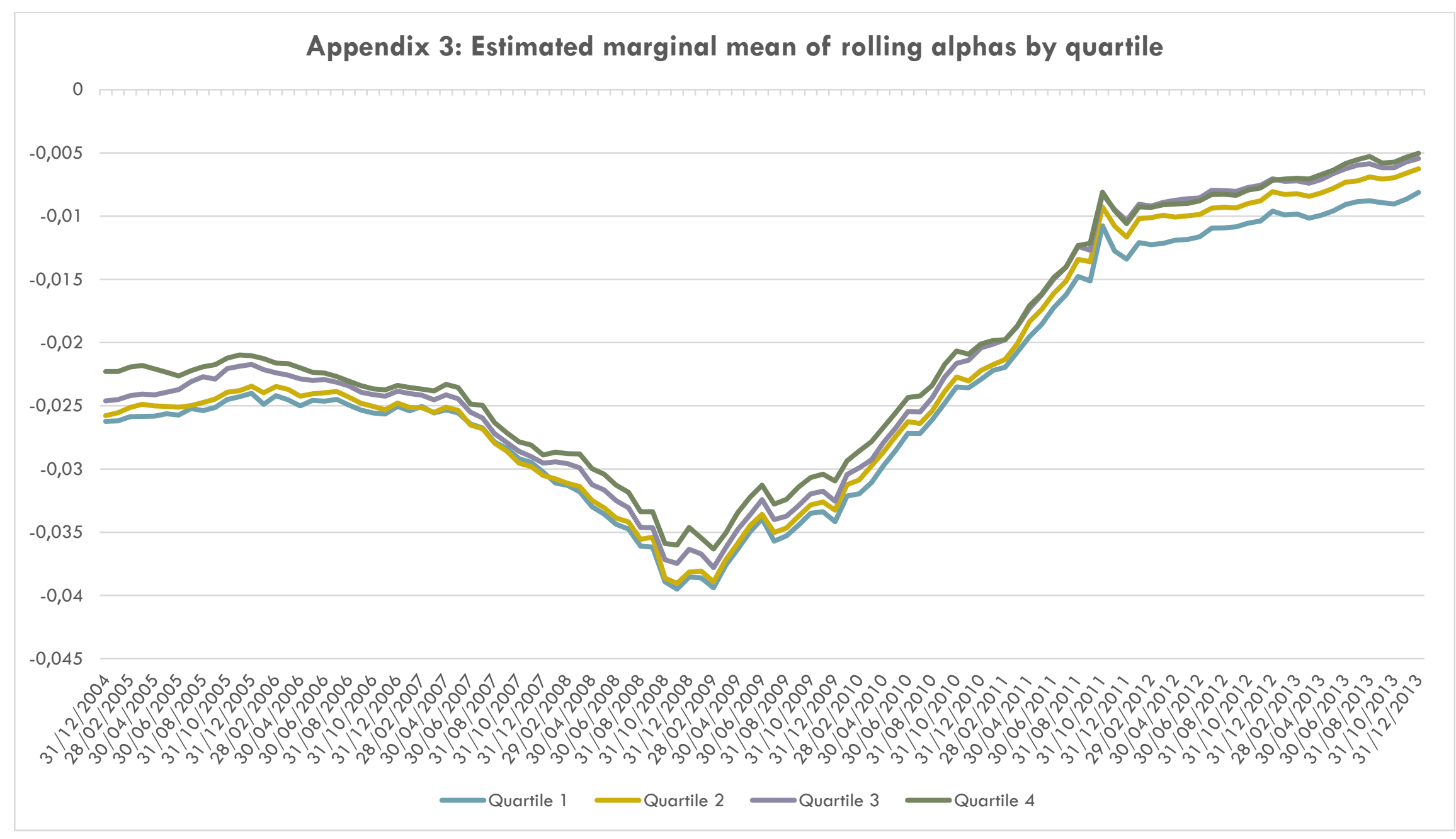




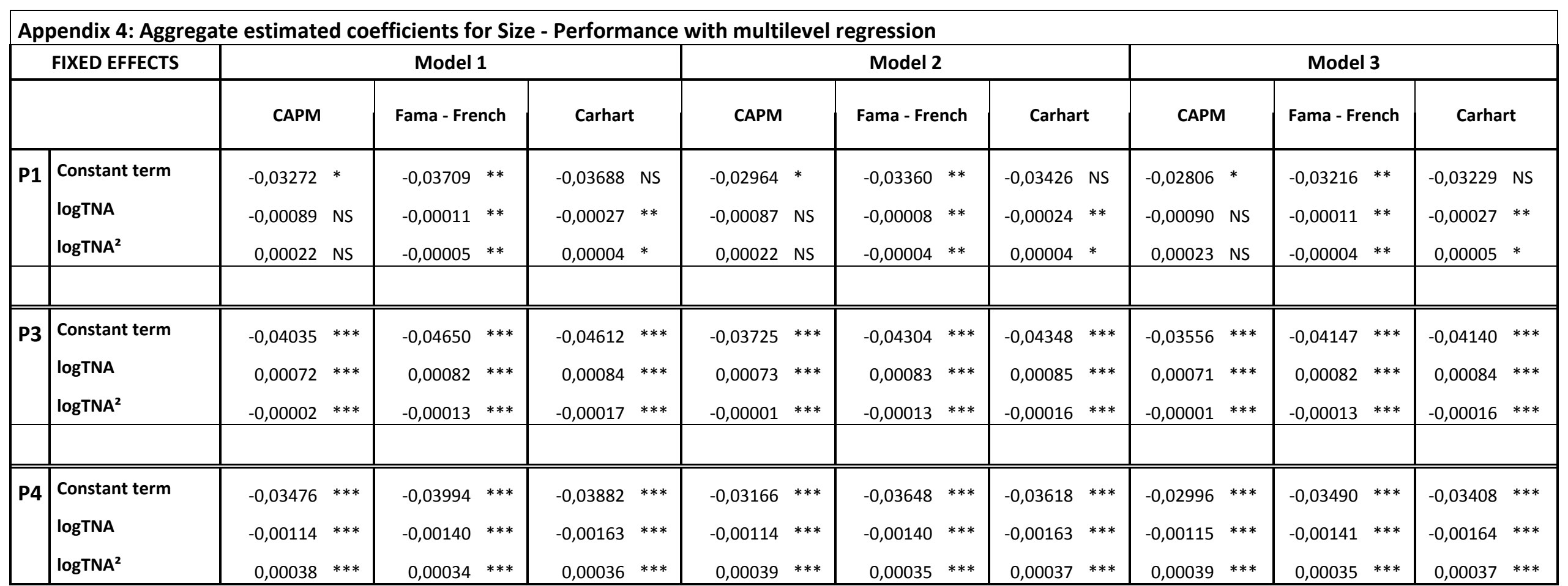

